Illinois State University

ISU ReD: Research and eData

Theses and Dissertations

3-28-2019

\title{
Nitrogen and Phosphorus Uptake in an Urban Stream Ecosystem
}

Nicolette A. Sheffield

Illinois State University, nicolette.sheffield@snc.edu

Follow this and additional works at: https://ir.library.illinoisstate.edu/etd

Part of the Geochemistry Commons, Geology Commons, and the Hydrology Commons

\section{Recommended Citation}

Sheffield, Nicolette A., "Nitrogen and Phosphorus Uptake in an Urban Stream Ecosystem" (2019). Theses and Dissertations. 1111.

https://ir.library.illinoisstate.edu/etd/1111

This Thesis is brought to you for free and open access by ISU ReD: Research and eData. It has been accepted for inclusion in Theses and Dissertations by an authorized administrator of ISU ReD: Research and eData. For more information, please contact ISUReD@ilstu.edu. 


\section{NITROGEN AND PHOSPHORUS UPTAKE \\ IN AN URBAN STREAM ECOSYSTEM}

\section{NICOLETTE A. SHEFFIELD}

44 Pages

Urban stream ecosystems are faced with high input levels of nitrogen $(\mathrm{N})$ and phosphorus (P) from anthropogenic activities. $\mathrm{N}$ and $\mathrm{P}$ are important to plant growth and stream health; however, high levels can lead to algal blooms and eutrophication, a harmful effect to both aquatic life and water quality. Common urban sources of $\mathrm{N}$ and $\mathrm{P}$ include fertilizer, atmospheric deposition, stormwater outfall, and leaf-litter decomposition. Common urban stream features such as a flashier hydrograph, altered channel stability and morphology, increase in nutrient output (such as $\mathrm{N}$ and $\mathrm{P}$ ), and heat retention, have been shown to result in an overall decrease in stream biodiversity. High input levels of $\mathrm{N}$ are seen within the Mississippi River Basin in the form of nitrate. In urban systems, estimates of loading of $\mathrm{N}$ and $\mathrm{P}$ into the Mississippi River Basin range from $7-9 \%$ for total $\mathrm{N}$ and $12-16 \%$ for $\mathrm{P}$.

This study focused on urban stream nutrient uptake along concrete-lined channels. Tributaries of Sugar Creek in Bloomington-Normal, IL, served as the study area. I hypothesized that concrete-lined channels limit nutrient uptake and maintain higher concentrations of $\mathrm{N}$ and $\mathrm{P}$ uptake. Measuring nutrient uptake involved short-term $\mathrm{N}$ and $\mathrm{P}$ additions. Samples tested for nitrate were analyzed on a Dionex ion chromatograph, while samples tested for dissolved reactive phosphate were analyzed following the molybdate method using spectrophotometry. Both $\mathrm{N}$ and $\mathrm{P}$ uptake velocities measured higher along urban concrete streams as compared to 
studies conducted in other environments such as deserts and forested areas. In addition, monthly uptake velocities were compared across the study sites, resulting in greater P uptake velocities over $\mathrm{N}$ uptake velocities.

Many urban streams were modified to manage for hydrology, potentially altering nutrient processing. Thus, quantifying nutrient uptake along a modified streambed will identify how $\mathrm{N}$ and $\mathrm{P}$ are retained within a stream ecosystem and have implications for stream system restoration.

KEYWORDS: nutrient uptake; nitrogen; phosphorous; urban stream; concrete-lined channel 


\section{NITROGEN AND PHOSPHORUS UPTAKE \\ IN AN URBAN STREAM ECOSYSTEM}

NICOLETTE A. SHEFFIELD

A Thesis Submitted in Partial Fulfillment of the Requirements for the Degree of

\section{MASTER OF SCIENCE}

Department of Geography, Geology, and the Environment

\section{ILLINOIS STATE UNIVERSITY}


Copyright 2019 Nicolette A. Sheffield 


\section{NITROGEN AND PHOSPHORUS UPTAKE}

IN AN URBAN STREAM ECOSYSTEM

NICOLETTE A. SHEFFIELD

COMMITTEE MEMBERS:

Catherine M. O'Reilly, Chair

William L. Perry

Eric W. Peterson 


\section{ACKNOWLEDGMENTS}

I would like to extend thanks to the people that made this project successful, beginning with the support and guidance of my advisor and committee: Drs. Catherine O'Reilly, William Perry, and Eric Peterson. Thanks to my fellow field hands: J. Epperson, G. Sieggreen, P. Konop, A. Oberhelman, and H. Gregorich. Gracious funding and use of lab space and equipment from Geological Society of America, Illinois State University, Laboratory for Environmental Analysis, and K. Theesfeld. Of equal importance, gratitude to my teachers and professors that brought me to this stage in my life, and those that challenge me to explore further. Finally, to my

parents, family, old and new friends, thank you for the continued encouragement, patience and grounding.

N. A. S. 


\section{CONTENTS}

Page

ACKNOWLEDGMENTS

$\begin{array}{lll}\text { TABLES } & \text { iii }\end{array}$

FIGURES

$\begin{array}{ll}\text { CHAPTER I: INTRODUCTION } & 1\end{array}$

$\begin{array}{ll}\text { Research Goals } & 6\end{array}$

$\begin{array}{lr}\text { CHAPTER II: METHODS } & 8\end{array}$

$\begin{array}{lr}\text { Site Description } & 8\end{array}$

Field Collection and Lab Analyses $\quad 11$

$\begin{array}{ll}\text { Calculating Discharge } & 13\end{array}$

$\begin{array}{ll}\text { Calculating Nutrient Uptake } & 13\end{array}$

$\begin{array}{ll}\text { In-stream Biota Determination } & 15\end{array}$

$\begin{array}{ll}\text { CHAPTER III: RESULTS } & 16\end{array}$

$\begin{array}{ll}\text { CHAPTER IV: DISCUSSION } & 25\end{array}$

$\begin{array}{ll}\text { Study Comparisons } & 25\end{array}$

$\begin{array}{ll}\text { Nutrient Uptake Implications } & 27\end{array}$

$\begin{array}{ll}\text { Sugar Creek Water-Quality } & 28\end{array}$

$\begin{array}{ll}\text { CHAPTER V: CONCLUSION } & 30\end{array}$

$\begin{array}{ll}\text { REFERENCES } & 32\end{array}$

$\begin{array}{ll}\text { APPENDIX A: FIELD OBSERVATIONS } & 37\end{array}$ 


\section{TABLES}

Table

Page

1. Chloride $(\mathrm{Cl})$ concentrations and corresponding drip rate used in calculating discharge

(Q) for each site

2. Nitrogen-nitrate, phosphorus and chloride background and plateau concentrations measured at each site

3. Nutrient spiraling metrics measured along sampled sections

4. Uptake velocities determined in different environments, as compared to this study's findings 


\section{FIGURES}

Figure $\quad$ Page

$\begin{array}{ll}\text { 1. Nutrient spiraling may be affected by streambed composition } & 7\end{array}$

2. Sampled sites along tributaries of Sugar Creek, Bloomington-Normal, Illinois 10

3. Field sampling set-up $\quad 11$

4. Comparison of $\mathrm{N}$ uptake velocity $\left(\mathrm{v}_{\mathrm{f}} \mathrm{N}\right)$ of sampling sites expressed as a function of background nitrate concentrations (N BKD)

5. Comparison of $\mathrm{P}$ uptake velocity $\left(\mathrm{v}_{\mathrm{f}} \mathrm{P}\right)$ of sampling sites expressed as a function of background phosphorous concentrations (P BKD)

6. Monthly uptake values according to each site

7. Nitrogen and phosphorus uptake correlations

8. Statistical mean resulting from t-test of $\mathrm{N}$ and $\mathrm{P}$ uptake velocities in the presence and absence of leaves in the study reach of the stream 


\section{CHAPTER I: INTRODUCTION}

The continuous increase in urbanization has led to greater modifications of natural landscapes, especially seen in urban waterways. It is estimated $55 \%$ of the world's population reside in urban areas, with $68 \%$ of the world population projected to live in cities by 2050 (UN DESA, 2018). The increase in urban development has brought disruption to urban stream ecosystems through various ways: flashier hydrograph, altered or restricted stream channel stability and morphology, increase in nutrient outputs, and an increase in temperature and heat retention (Booth et al., 2016; Walsh et al., 2005). All these factors result in an overall decrease in stream biodiversity (Walsh et al., 2005).

Seasonal precipitation can cause various contaminants to flow into nearby river systems, especially true for urban areas where there are greater impermeable surfaces, such as concrete sidewalks and parking lots that allow greater mobility of contaminant transport. For example, when heavy rains envelop the area, the storm sewer systems cannot handle large influxes of rainwater and much of the rain runs directly into streams rather than transported to treatment plants (EPA, 2017a). With the runoff of urban contaminants flushing into local waters, there is a negative effect on the ecosystem downstream. Urban waterways are connected to larger water bodies; this includes rivers, lakes, reservoirs, and coastal waters. Excess inputs of nutrients (primarily nitrogen and phosphorus) are seen within the Mississippi River Basin, resulting in hypoxic waters in the Gulf of Mexico (Robertson and Saad, 2013). In urban systems, estimates of nitrogen and phosphorus loading into the Mississippi River Basin range from 7-9\% for total nitrogen and 12-16\% for phosphorus (Alexander et al., 2008; Robertson and Saad, 2013).

Nitrogen $(\mathrm{N})$ and phosphorus $(\mathrm{P})$ are commonly studied as the two main contaminants in urban waters due to their abundance. $\mathrm{N}$ and $\mathrm{P}$ are key nutrients within an ecosystem; however, at 
large concentrations they can lead to algal blooms and eutrophication, a harmful effect to both stream life and water quality. Illinois' EPA maximum contaminant level for $\mathrm{P}$ is $0.05 \mathrm{mg} / \mathrm{L}$ in waters from any reservoir or lake with a surface area of 8 hectares (20 acres) or more, or in any stream waters at the point where it enters a reservoir or lake (EPA, 2017b). $\mathrm{N}$ in the form of nitrate and ammonia are regulated at $10.0 \mathrm{mg} / \mathrm{L}$ and $1.9 \mathrm{mg}$ total ammonia nitrogen per liter at $\mathrm{pH} 7,20^{\circ} \mathrm{C}$ for a 30 -day average duration and not to be exceeded more than once every 3 years on average (EPA, 2017b; EPA, 2013). An assessment of $\mathrm{N}$ and $\mathrm{P}$ budgets of urban watersheds resulted in a call for reducing watershed inputs of $\mathrm{N}$ and $\mathrm{P}$, with additional focus on reducing the transport of P from vegetated landscapes to streets and storm drains (Janke et al., 2017; Hobbie et al., 2017). Within the Minneapolis-St. Paul urban watersheds, 37-59\% and 19-34\% of N input originated from lawn fertilizers and atmospheric deposition respectively, whereas $76 \%$ and 13 $33 \%$ of $\mathrm{P}$ input originated from pet waste and atmospheric deposition (Hobbie et al., 2017). Additional sources contributing to $\mathrm{N}$ and $\mathrm{P}$ inputs in urban environments include storm drain export, street sweeping export, and grass and leaf litter decay (Janke et al., 2014; Hobbie et al., 2014). These are the potential urban sources that contribute to the growing hypoxic water of the Gulf of Mexico. Understanding and focusing on $\mathrm{N}$ and $\mathrm{P}$ processes along urban waterways may help in the reduction of urban nutrient output percentages.

A method for understanding nutrient processes within a stream involves studying nutrient dynamics (Webster and Patten, 1979; Newbold et al., 1982; Minshall et al., 1983; Ensign and Doyle, 2006). Nutrient spiraling describes the path taken by the nutrient atom in relation to the biotic demand and features of the water column, such as depth and discharge (Newbold et al., 1982). A greater hydraulic retention of nutrients within the system allows more biogeochemical processes to occur, so in a stream with high retention and high biological activity, the nutrient 
spiral is short and fast. Conversely, in a stream with low retention and low biological activity, a nutrient spiral is looser, elongated, and slow. A looser nutrient spiral suggests nutrients to more likely export downstream due to the lack of uptake (Minshall et al., 1983). The characteristics of a spiral is indicative of uptake length, how far a nutrient atom travels, and uptake velocity, how fast a nutrient atom is being drawn down from the water column due to biotic demand (Webster and Patten, 1979; Tank et al., 2006). Uptake lengths and uptake velocities have been measured in different stream environments along different streambed compositions (Grimm et al., 2005; Hoellein et al., 2007; Rushford and Hershey, 2009; Merseburger et al., 2011; Bott and Newbold, 2013); however, a specific type of streambed composition has been understudied—urban concrete-lined channels. Of the five sources previously listed, Grimm et al. (2005) provides data for concrete-lined streams, but it is not the main focus of their research. In their study, concretelined channels were grouped with 'earthen' streambeds under the label 'urban streams'. Results suggest urban streams to be lower in $\mathrm{N}$ retention yet have longer uptake lengths as compared to unaltered desert streams. $\mathrm{N}$ uptake velocities specifically measured along concrete-lined channels equaled 0.056 and $0.120 \mathrm{~mm} / \mathrm{s}$ (Grimm et al., 2005). Nutrient uptake dynamics of concrete-lined streams are still in question. Research on concrete-lined channels may help shed light on decreasing nutrient loads in urban watershed environments, as well as reducing harmful effects downstream.

Urban concrete-lined channels are constructed for multiple purposes, such as flood control, preventing channel bank erosion, and protecting streams from seepage loss. In addition, concrete channels are simple to construct, cost efficient, and low maintenance (US ACE, 1995). Notable urban concrete-lined channels in the United States include the Los Angeles River in California, Houston Bayou System in Texas, and Highline Canal in southern Phoenix, Arizona. 
Modified stream channels could potentially alter nutrient processing by limiting interactions with the streambed, specifically interactions within the hyporheic zone; the zone underlying the streambed in which surface waters mix with groundwater (Winter et al., 1998). The hyporheic zone plays a major role in the exchange of water, nutrients and organic matter (Boulton et al. 1998); therefore, stream modification may result in an increase transmission of contaminants downstream rather than potential processing in the stream.

Microbes within the hyporheic zone play a significant role in stream metabolism through biogeochemical processes such as oxidation-reduction reactions. The exchange between groundwater and surface waters host chemical transfers, supplying carbon, oxygen, nitrogen and phosphorus necessary for biogeochemical processes. Streambed characteristics can affect chemical concentrations. For example, a coarse streambed allows oxygen-rich stream water to more easily enter the hyporheic zone and mix with groundwater, stimulating levels of microbial activity (Winter et al., 1998). Aerobic microbial processes occur near the streambed in the upper section of the hyporheic zone interacting mostly with the oxygen-rich surface water, whereas anaerobic microbial processes occur deeper in the hyporheic zone near the groundwater (Winter et al., 1998). $\mathrm{N}$ can be metabolized through reactions of nitrification (from aerobic processes) or denitrification (from anaerobic processes). Nitrification is the reaction in which ammonium is oxidized to nitrate: $\mathrm{NH}_{4}{ }^{+}+2 \mathrm{O}_{2} \rightarrow \mathrm{NO}_{3}{ }^{-}+\mathrm{H}_{2} \mathrm{O}+2 \mathrm{H}^{+}$(net reaction of two-step process), and

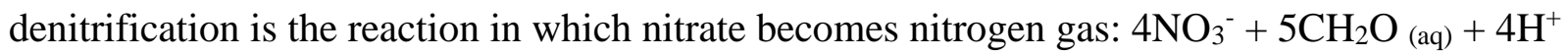
$\rightarrow 2 \mathrm{~N}_{2}+7 \mathrm{H}_{2} \mathrm{O}+5 \mathrm{CO}_{2}$ (Eby, 2004). Nutrient uptake studies focus on these reactions that measure the release of nitrate and ammonia back into the water column.

Microbes can be subdivided into groups based on how they obtain carbon and energy: autotrophs and heterotrophs. Autotrophs obtain carbon from carbon dioxide $\left(\mathrm{CO}_{2}\right)$, bicarbonate 
$\left(\mathrm{HCO}_{3}{ }^{-}\right)$, or carbonate $\left(\mathrm{CO}_{3}{ }^{2-}\right)$ ions, in addition to other forms of external energy for their synthesis of organic compounds. Heterotrophs use previously synthesized carbon and obtain energy through oxidation of organic compounds (Eby, 2004). Nutrient retention in a stream can vary depending on the benthic life present such as heterotrophic or autotrophic-dominated streams (Schade et al., 2011). Studies done by Schade et al. (2006) suggest algae have a greater capacity to store nutrients as compared to bacteria, and that heterotrophic streams are more 'homeostatic' in response to fluctuating nutrient concentrations in-stream.

This study focused on nutrient spiraling of $\mathrm{N}$ and $\mathrm{P}$ through measuring nutrient uptake velocities along an urban concrete-lined channel. Quantifying the influence of modified urban streams on nutrient uptake may identify how $\mathrm{N}$ and $\mathrm{P}$ are retained within a stream ecosystem and have implications for stream system restoration. 


\section{Research Goals}

I conducted this study to measure $\mathrm{N}$ and $\mathrm{P}$ uptake along a concrete-lined channel in an urban stream ecosystem to answer the following: How do $N$ and $P$ uptake along concrete-lined channels compare to other stream environments? Are the resulting uptake velocities similar across the selected study sections or do the values differ? Are there monthly variations in nutrient uptake among the sample sites?

1. Nutrient spiraling within a natural stream bed is greatly influenced by biogeochemical processes of the microbes within the hyporheic zone in contrast to a concrete-lined stream bed that has no hyporheic zone to aid in processing nutrients (Figure 1); therefore, I hypothesize uptake velocity values to be lower along concrete-lined channels, as compared to streams that have a defined hyporheic zone $\left(v_{f}\right.$ natural $>v_{f}$ concrete).

2. Additionally, I hypothesize nutrient uptake to differ between the sampling months of late summer to early fall, specifically corresponding to the nutrient loads in the stream for each season. I propose summer to have a greater $\mathrm{P}$ uptake velocity due to abundance of $\mathrm{N}$ in stream from fertilizers, while fall having greater $\mathrm{N}$ uptake due to abundance of $\mathrm{P}$ from the decomposition of leaf litter. 


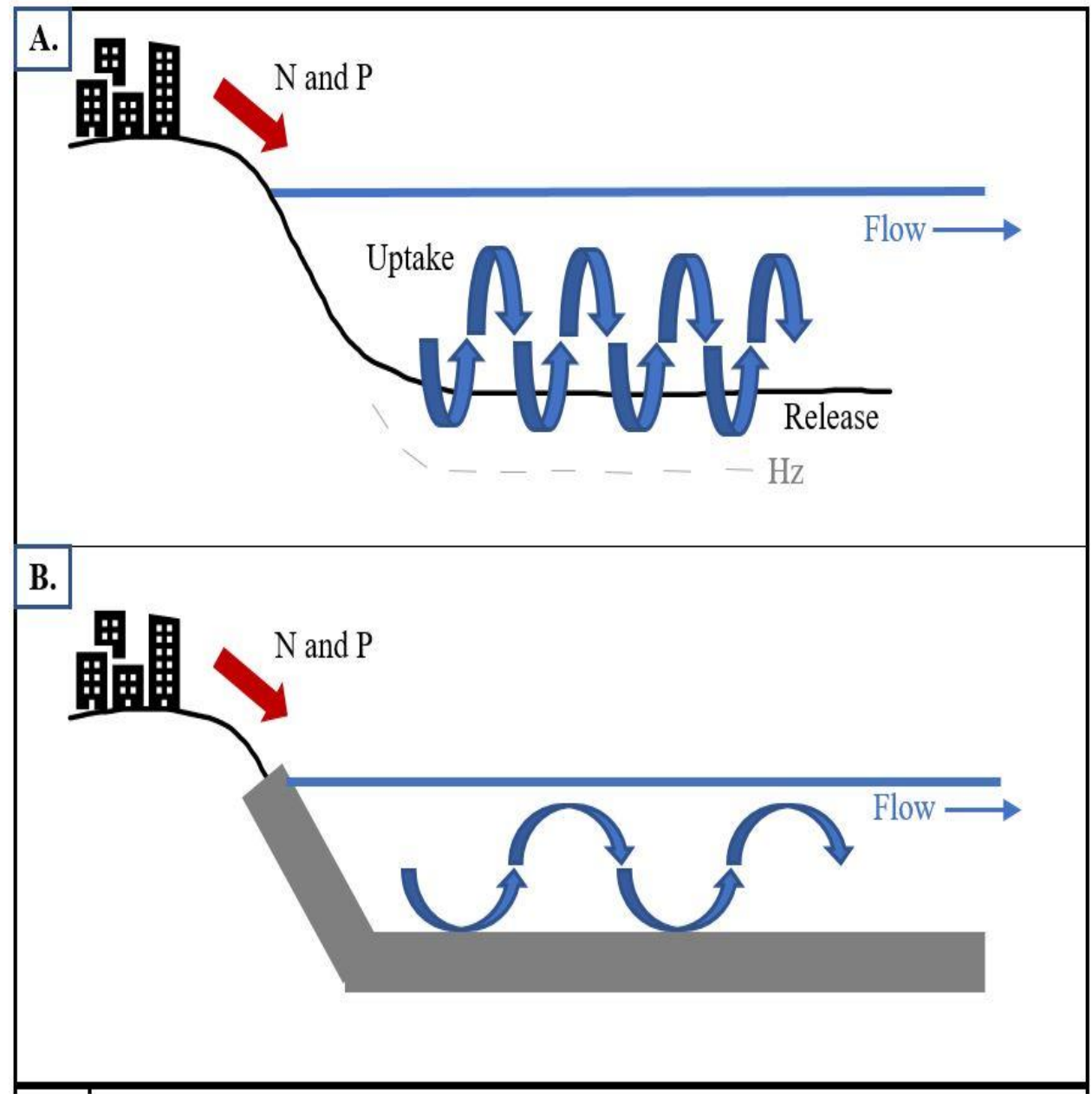

Figure 1: Nutrient spiraling may be affected by streambed composition. A natural stream bed (A.) will possess a tighter nutrient spiral due to the greater amount of uptake through the hyporheic zone $(\mathrm{Hz})$, whereas in a concrete-lined stream bed (B.) there is less interaction with the hyporheic zone and microbes, resulting in a looser nutrient spiral and lower uptake velocity values. 


\section{CHAPTER II: METHODS}

\section{Site Description}

The stream system in this study is Sugar Creek; it runs through the towns of Bloomington-Normal in central Illinois, among neighborhoods and commercial industry. Sugar Creek is a second-order stream within the Sangamon River Basin (3,690 km²) (IDNR, 2000), beginning on the east side of Normal flowing southwest passed city limits until joining Salt Creek near New Holland, IL (approximately 72 kilometers southwest of Normal). Streams within the vicinity of Bloomington-Normal have both an urban and rural influence on what contaminants are being transported; however, the reaches along Sugar Creek that were in study are greatly influenced by urban inputs (IDNR, 2000).

Three concrete-lined sections of Sugar Creek were chosen to be sampled from July 2018 through November 2018. Sampling sites were located on tributaries of Sugar Creek and are surrounded by mixed-urban land use. Sites include: Adelaide Street, Eastholme Avenue, and Ewing Park II (Figure 2). The Adelaide location was southwest of Illinois State University campus, west of the Tri Tower dormitory. The surrounding area by the sampled section of stream was a residential street to the west and parking lot to the east. Tall grasses lined either side of the concrete channel with few aquatic plants found in the reach. Some trees were in proximity of the sampled channel section as well. Eastholme was a residential area with backyards on either side of the stream section. Few to no trees were within proximity of the sampled section, and some grasses and aquatic plants grew along the concrete seams in the channel. Lastly, Ewing was located just outside the park with the surrounding area being residential. Backyards were found behind a tree line to the north, and park space was to the south of the sampled section. Ewing's concrete channel was the widest compared to the other two sites and had no plants near or within 
the stream channel. Characteristics among these sampling sites are similar in lacking sinuosity, sediment, and variation in width and depth.

Precipitation is important in the context of recharge levels and maintaining flow in Sugar Creek. Central Illinois receives an annual average of 99 centimeters of precipitation in the form of rain and 53 centimeters in snowfall (US Climate Data, 2019). Dry conditions have periodically persisted from summer into fall within the region; however, none of the three chosen sampling sites dried during the course of this study. Conversely, heavy rains have enveloped the area sometimes causing delay in sampling due to the washing out of the microbial and algal communities in Sugar Creek. During these large fluxes, one to two weeks was given for regrowth of colonies. 


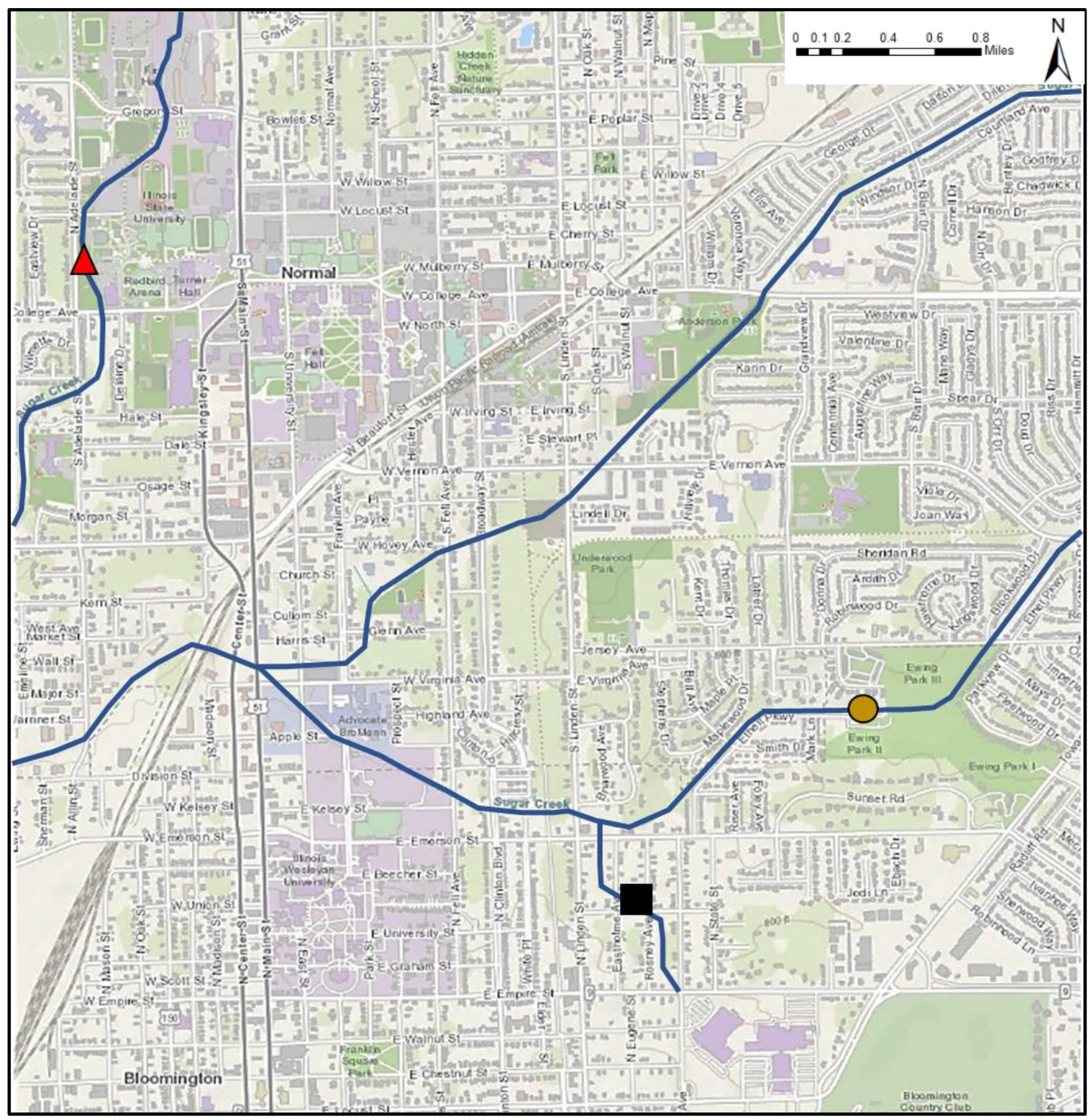

Figure 2: Sampled sites along tributaries of Sugar Creek, Bloomington-Normal, Illinois. Three concrete-lined channel sections were sampled: Adelaide Street (red triangle), Eastholme Avenue (black square), and Ewing Park (gold circle). 


\section{Field Collection and Lab Analyses}

In this specific study, short-term uptake of nitrate and soluble reactive phosphorus were measured following the methodology of Tank et al. (2006). Five transects were spaced 20 meters apart along the channel in the downstream direction from the injection pump (Figure 3). In some cases, a mixing zone was added between the injection pump location and the first transect to create a more well-mixed solution along the reach. A longer mixing zone was indicative of slow stream flow, whereas a shorter zone was indicative of fast stream flow.

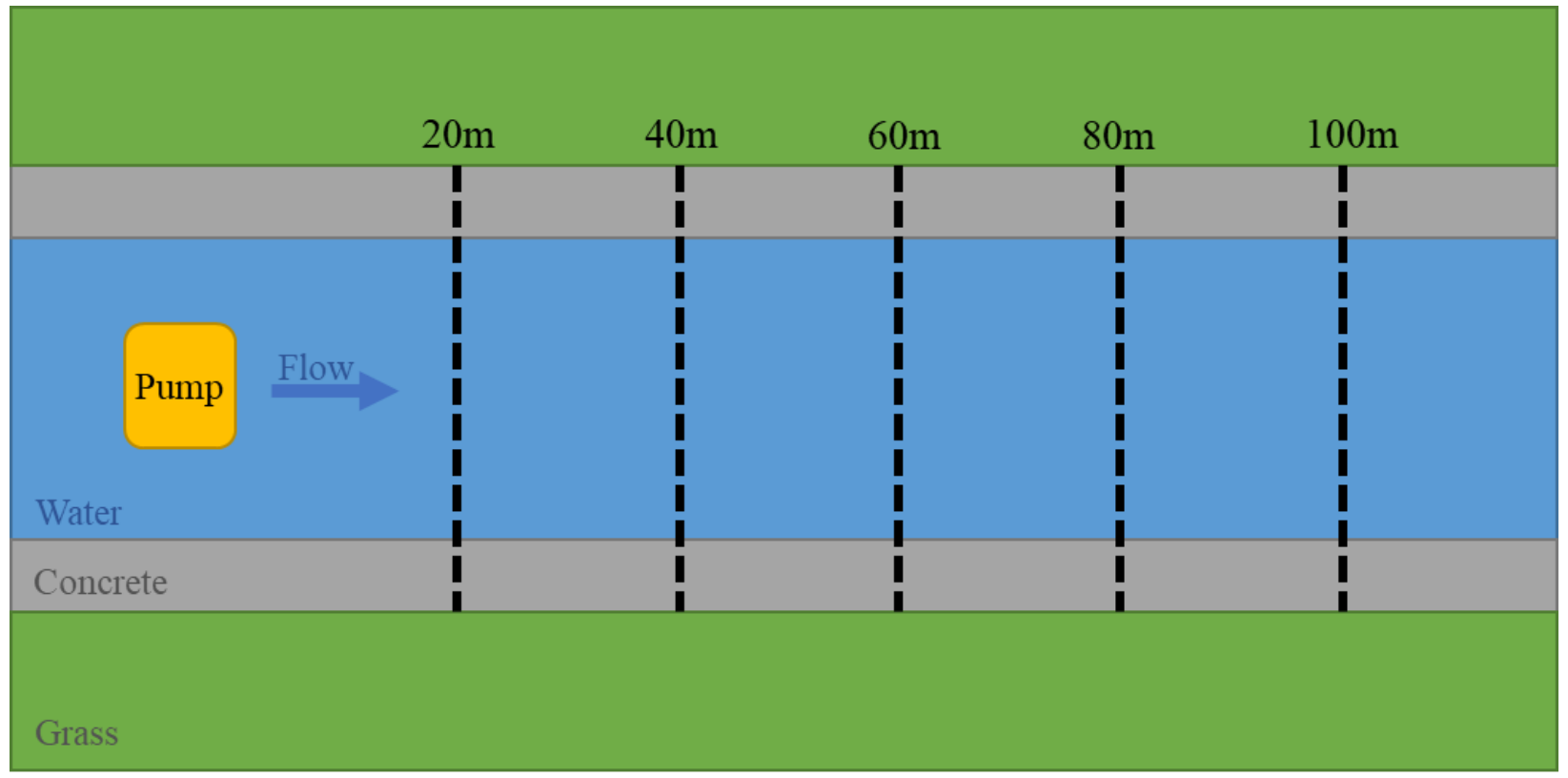

Figure 3: Field sampling set-up; five transects were measured 20m apart downstream from injection pump, totaling to $100 \mathrm{~m}$ study reach. 
Background samples were taken at each transect before any nutrient solution additions. Concentrated sodium nitrate and monobasic potassium phosphate salts with sodium chloride were dripped in-stream at a steady rate until concentrations came to a stable maximum or plateau along the reach. A YSI ProPlus was used to check specific conductance $(\mathrm{SpC})$ at each of the transects; when the $\mathrm{SpC}$ value was stable and within the same range at each transect, the nutrient solution was assumed to be evenly mixed throughout the reach. The addition of sodium chloride served as a tracer accounting for any dilution over the course of the reach, as well as the indicator of solution plateau. At plateau, three samples were collected at each of the five transects. Water samples were filtered through a syringe filter $(25 \mathrm{~mm})$, and stored on ice until returning to the laboratory, where they were frozen until analysis. Lastly, wetted width was measured.

Analysis of the collected water samples were conducted in the Laboratory for Environmental Analysis at Illinois State University. Samples tested for nitrogen as nitrate were analyzed on a Dionex Ion Chromatograph 1100. Samples tested for phosphate were analyzed following the standard EPA molybdate method using spectrophotometry (EPA, 1978) for dissolved reactive phosphorus. 


\section{Calculating Discharge}

Discharge (Q) was not measured in the field due to the shallow water column of Sugar Creek; rather, discharge was calculated following Webster and Valett (2006) on dynamics of conservative solutes. Concentrations of the nutrient or release solution, stream concentrations and drip rate were used as:

$$
\mathrm{Q}=\frac{(\mathrm{Cr}-\mathrm{Cb}) \mathrm{Qr}}{\mathrm{Cp}-\mathrm{Cb}}
$$

where $\mathrm{Cr}$ is concentration of the release solution $(\mathrm{mg} / \mathrm{L})$; $\mathrm{Cb}$ is concentration of background $(\mathrm{mg} / \mathrm{L}) ; \mathrm{Cp}$ is concentration of plateau $(\mathrm{mg} / \mathrm{L})$; and Qr is drip rate $(\mathrm{L} / \mathrm{s})$.

Before values were plugged into the above equation, the release solution concentration (Cr) was diluted prior to running on the ion chromatograph, so the original concentration had to be calculated. Thus, the dilution equation $\left(\mathrm{C}_{1} \mathrm{~V}_{1}=\mathrm{C}_{2} \mathrm{~V}_{2}\right)$ was used, solving for $\mathrm{C}_{1}$ as $\mathrm{Cr}$. All other concentrations and volumes were known to calculate $\mathrm{Cr}$ : diluted chloride concentration $\left(\mathrm{C}_{2}\right)$, and the dilution amount $\left(\mathrm{V}_{1}\right)$ into the volumetric flask $\left(\mathrm{V}_{2}\right)$. Using the resulting $\mathrm{Cr}$ value discharge was then calculated. Lastly, discharge values were converted from liters per second to cubic meters per second to aid in calculating uptake velocities.

\section{Calculating Nutrient Uptake}

From the resulting chemical analyses, uptake length $\left(S_{w}\right)$ and uptake velocity $\left(v_{f}\right)$ were calculated using discharge (Table 1), distance between transects, and background concentrations (Table 2). Uptake length was calculated by using an exponential decay model:

$$
\ln \mathrm{C}_{\mathrm{x}}=\ln \mathrm{C}_{0}-k x
$$

where $\mathrm{C}_{\mathrm{x}}$ is the background-corrected plateau concentration at $x$ meters downstream from the injection point; $\mathrm{C}_{0}$ is the background-corrected concentration at the injection point site $(0 \mathrm{~m}) ; k$ is 
the exponential decay rate of the concentrations. Nutrient concentrations were divided by the background-corrected plateau tracer concentrations for each sample transect. A linear regression between the natural log of the nutrient to tracer ratio and distance from injection was plotted to represent the decay rate $(k)$. It is the inverse of the linear regression slope that equals uptake length $\left(\mathrm{S}_{\mathrm{w}}\right)$ :

$$
\mathrm{S}_{\mathrm{W}}=k^{-1}
$$

If the nutrient concentration increased over the course the reach, there was no measurable uptake. Uptake length can only be calculated if there is a decrease in the concentration of the nutrient. The tracer concentration was assumed to be the same throughout the reach (unless dilution occurred), meaning the ratio of nutrient to tracer became smaller farther downstream.

Uptake velocity $\left(\mathrm{v}_{\mathrm{f}}\right)$ is described as the biotic demand or velocity at which $\mathrm{N}$ and $\mathrm{P}$ are removed from the water column through uptake processes. Using the same $k$ value as previously calculated in $\mathrm{S}_{\mathrm{w}}$, a velocity was determined by $k$ times discharge (Q) over the wetted width of the channel $(w)$ :

$$
\mathrm{V}_{\mathrm{f}}=\mathrm{Q} k / w
$$

Uptake velocity values were focused on and compared in this study. Uptake velocities rather than uptake lengths are compared across studies because uptake velocity accounts for differences in discharge among streams, whereas uptake lengths are strongly influenced by stream discharge. Further analyses with resulting values were tested for statistical significance in RStudio 3.5.1 or Excel. Statistical models ran in RStudio included linear regression analyses, correlations, Shapiro-Wilk and homoscedasticity, while paired t-tests were done in Excel. 


\section{In-stream Biota Determination}

There were no quantitative tests performed to measure algal growth in the stream, instead growth was determined by observation. Field observations were classified as three degrees of growth: low, medium, and high. Low algal growth consisted of clear waters with little to no algae seen. Medium algal growth consisted of thin layering, matting, or strips of algae. High algal growth consisted of thicker, denser, sponge-like algal mats. Field conditions and photographs were recorded and taken during each sampling, excluding 7/23/2018 and 8/8/2018, no photos were taken during these dates (Appendix A). In addition, presences and absence of leaves and cut grass were also noted as general field observations (Table 3). 


\section{CHAPTER III: RESULTS}

A total of ten successful field runs were performed along the concrete-lined sections of the Sugar Creek tributaries from July to October 2018; Adelaide was sampled three times, Eastholme four times, and Ewing three times.

Resulting chloride concentrations and drip rate values were used in calculating stream discharge (Table 1). Discharge varied each sample run. Discharge for Adelaide ranged from 11.5 to $49.8 \mathrm{~L} / \mathrm{s} ; 0.9$ to $68.0 \mathrm{~L} / \mathrm{s}$ at Eastholme; and 2.6 to $46.9 \mathrm{~L} / \mathrm{s}$ at Ewing (Table 1 ). In some cases, the nutrient-salt solution diluted ambient chloride concentrations, as seen for AD 10/16, EL 10/23, and EW 9/15, where the chloride plateau concentrations measured lower; however, nutrient concentrations for these runs were not affected by the dilution (Table 2).

Table 1: Chloride $(\mathrm{Cl})$ concentrations and corresponding drip rate used in calculating discharge (Q) for each site. Recorded average specific conductance is also noted. Site names noted as: AD (Adelaide), EL (Eastholme), and EW (Ewing).

\begin{tabular}{|c|c|c|c|c|c|c|c|c|}
\hline \multirow[t]{2}{*}{ Site } & \multirow[t]{2}{*}{ Date } & $\begin{array}{c}\text { Average } \\
\text { Specific } \\
\text { Conductance }\end{array}$ & $\begin{array}{l}\text { Cl Release } \\
\text { (Diluted) }\end{array}$ & $\begin{array}{c}\text { Cl } \\
\text { Background }\end{array}$ & Cl Plateau & Drip Rate & $\mathbf{Q}$ & $\mathbf{Q}$ \\
\hline & & $\boldsymbol{\mu S} / \mathbf{c m}$ & $\mathrm{mg} / \mathrm{L}$ & $\mathrm{mg} / \mathrm{L}$ & $\mathrm{mg} / \mathrm{L}$ & L/s & $\mathrm{L} / \mathrm{s}$ & $\mathrm{m}^{3} / \mathrm{s}$ \\
\hline $\mathrm{AD}$ & 23-Jul & 1236 & 21.9 & 308.7 & 343.9 & 0.0037 & 11.5 & 0.012 \\
\hline $\mathrm{AD}$ & 19-Sep & 1622 & 18.6 & 787.0 & 792.7 & 0.0031 & 49.8 & 0.050 \\
\hline $\mathrm{AD}$ & 16-Oct & 1100 & 18.1 & 244.7 & 226.3 & 0.0026 & 12.6 & 0.013 \\
\hline EL & 5-Sep & 2162 & 20.4 & 836.3 & 1212.8 & 0.0032 & 0.9 & 0.001 \\
\hline EL & 23-Sep & 2068 & 17.2 & 631.0 & 818.4 & 0.0029 & 1.3 & 0.001 \\
\hline EL & 14-Oct & 1266 & 19.0 & 307.1 & 322.6 & 0.0030 & 18.5 & 0.019 \\
\hline EL & 23-Oct & 1566 & 5.6 & 17.3 & 16.0 & 0.0032 & 68.0 & 0.068 \\
\hline EW & 8-Aug & 857 & 6.9 & 30.4 & 32.6 & 0.0030 & 46.9 & 0.047 \\
\hline EW & 15-Sep & 1232 & 19.8 & 743.1 & 624.7 & 0.0031 & 2.6 & 0.003 \\
\hline EW & 1-Oct & 1143 & 20.3 & 516.5 & 533.3 & 0.0032 & 19.2 & 0.019 \\
\hline
\end{tabular}


Nutrient and tracer background and plateau concentration values were used in calculating uptake (Table 2). $\mathrm{N}$ uptake lengths measured 200m, 385m at Adelaide; 47 to $185 \mathrm{~m}$ at Eastholme; and $41 \mathrm{~m}, 127 \mathrm{~m}$ at Ewing (Table 3). $\mathrm{N}$ uptake velocities measured $0.028 \mathrm{~mm} / \mathrm{s}, 0.112 \mathrm{~mm} / \mathrm{s}$ at Adelaide; 0.01 to $0.058 \mathrm{~mm} / \mathrm{s}$ at Eastholme; and $0.013 \mathrm{~mm} / \mathrm{s}, 0.312 \mathrm{~mm} / \mathrm{s}$ at Ewing (Table 3). P uptake lengths ranged 68 to $256 \mathrm{~m}$ at Adelaide; 40 to $435 \mathrm{~m}$ at Eastholme; and $62 \mathrm{~m}, 67 \mathrm{~m}$ at Ewing (Table 3). $\mathrm{P}$ uptake velocities ranged 0.024 to $0.356 \mathrm{~mm} / \mathrm{s}$ at Adelaide; 0.002 to 0.356 $\mathrm{mm} / \mathrm{s}$ at Eastholme; and $0.209 \mathrm{~mm} / \mathrm{s}, 0.226 \mathrm{~mm} / \mathrm{s}$ at Ewing (Table 3). Calculated uptake velocities for EL 10/23 and EW 8/8 resulted as zero, meaning there was no uptake measurable within the study reach. In the case of $\mathrm{AD} 10 / 16$, there was an increase in $\mathrm{N}$ over the reach; uptake length can only be calculated if there is a decrease in the concentrations, thus there was no uptake during that run. EW 9/15 P results were incorrectly processed; therefore, no $\mathrm{P}$ concentrations are available for that individual run (Table 3).

Table 2: Nitrogen-nitrate, phosphorus and chloride background and plateau concentrations measured at each site. Site abbreviations same as Table 1.

\begin{tabular}{|c|c|c|c|c|c|c|c|}
\hline \multirow{3}{*}{ Site } & \multirow{3}{*}{ Date } & \multicolumn{3}{|c|}{ Background Concentrations } & \multicolumn{3}{|c|}{ Plateau Concantrations } \\
\hline & & N-Nitrate & Phosphorus & Chloride & N-Nitrate & Phosphorus & Chloride \\
\hline & & $\mathrm{mg} / \mathrm{L}$ & $\mathrm{mg} / \mathrm{L}$ & $\mathrm{mg} / \mathrm{L}$ & $\mathrm{mg} / \mathrm{L}$ & $\mathrm{mg} / \mathrm{L}$ & $\mathrm{mg} / \mathrm{L}$ \\
\hline $\mathrm{AD}$ & 23-Jul & 0.5 & 0.018 & 308.7 & 1.7 & 2.5 & 343.9 \\
\hline $\mathrm{AD}$ & 19-Sep & 0.5 & 0.000 & 787.0 & 8.2 & 1.9 & 792.7 \\
\hline $\mathrm{AD}$ & 16-Oct & 1.8 & 0.020 & 244.7 & 1.9 & 0.4 & 226.3 \\
\hline EL & 5-Sep & 0.7 & 0.007 & 836.3 & 13.1 & 15.3 & 1212.8 \\
\hline EL & 23-Sep & 0.8 & 0.004 & 631.0 & 7.0 & 1.8 & 818.4 \\
\hline EL & 14-Oct & 2.3 & 0.014 & 307.1 & 3.3 & 1.1 & 322.6 \\
\hline EL & 23-Oct & 10.1 & 0.010 & 17.3 & 43.8 & 1.5 & 16.0 \\
\hline EW & 8-Aug & 24.9 & 0.033 & 30.4 & 20.5 & 1.2 & 32.6 \\
\hline EW & 15-Sep & 0.6 & N/A & 743.1 & 3.0 & N/A & 624.7 \\
\hline EW & 1-Oct & 0.2 & 0.008 & 516.5 & 3.8 & 1.2 & 533.3 \\
\hline
\end{tabular}


Table 3: Nutrient spiraling metrics measured along sampled sections; $\mathrm{v}_{\mathrm{f}}=$ uptake velocity, $\mathrm{S}_{\mathrm{w}}=$ uptake length. Recorded wetted width and observed algae and leaf presence are also noted. Site abbreviations same as previous tables.

\begin{tabular}{|c|c|c|c|c|c|c|c|c|}
\hline \multirow[t]{2}{*}{ Site } & \multirow[t]{2}{*}{ Date } & $\mathbf{S}_{\mathbf{w}} \mathbf{N}$ & $\mathbf{v}_{\mathbf{f}} \mathbf{N}$ & $\mathbf{S}_{\mathrm{w}} \mathbf{P}$ & $\mathbf{v}_{\mathbf{f}} \mathbf{P}$ & $\begin{array}{c}\text { Average } \\
\text { Wetted } \\
\text { Width }\end{array}$ & \multirow[t]{2}{*}{ Algae } & \multirow[t]{2}{*}{$\begin{array}{c}\text { Leaf } \\
\text { Presence }\end{array}$} \\
\hline & & $\mathbf{m}$ & $\mathbf{m m} / \mathbf{s}$ & $\mathbf{m}$ & $\mathbf{m m} / \mathbf{s}$ & $\mathbf{m}$ & & \\
\hline $\mathrm{AD}$ & 23-Jul & 200 & 0.028 & 68 & 0.083 & 2.0 & LOW & NONE \\
\hline $\mathrm{AD}$ & 19-Sep & 385 & 0.112 & 120 & 0.356 & 1.2 & MED & NONE \\
\hline $\mathrm{AD}$ & 16-Oct & N/A & N/A & 256 & 0.024 & 2.1 & MED & YES \\
\hline EL & 5-Sep & 101 & 0.010 & 435 & 0.002 & 1.1 & MED & NONE \\
\hline EL & 23-Sep & 47 & 0.040 & 40 & 0.047 & 0.7 & MED & YES \\
\hline EL & 14-Oct & 185 & 0.058 & 145 & 0.074 & 1.7 & LOW & YES \\
\hline EL & 23-Oct & N/A & N/A & N/A & N/A & 1.5 & HIGH & YES \\
\hline EW & 8-Aug & N/A & N/A & 67 & 0.226 & 3.1 & LOW & NONE \\
\hline EW & 15-Sep & 127 & 0.013 & N/A & N/A & 1.5 & LOW & NONE \\
\hline EW & $1-\mathrm{Oct}$ & 41 & 0.312 & 62 & 0.209 & 1.5 & LOW & YES \\
\hline
\end{tabular}

$\mathrm{N}$ uptake velocities were dependent on the ambient nitrate concentrations in-stream. High ambient concentrations of nitrate resulted in no measurable $\mathrm{N}$ uptake, as shown by Eastholme and Ewing when background concentrations measured $10.1 \mathrm{mg} / \mathrm{L}$ and $24.9 \mathrm{mg} / \mathrm{L}$ respectively (Figure 4). Conversely, lower ambient concentrations resulted in $\mathrm{N}$ uptake processes. $\mathrm{N}$ uptake velocity values were clustered at lower background concentrations with Adelaide measured at higher uptake velocities and Eastholme measured at lower $\mathrm{N}$ uptake velocities (Figure 4). Ewing had no conclusive results, measuring no uptake at high background concentrations and high uptake at low background concentrations (Figure 4). Collectively, a negative exponential trend was seen in the plotted data, indicative of a negative correlation $(r=-0.312)$ between $\mathrm{N}$ uptake velocity and background concentrations. A linear regression analysis of $\mathrm{N}$ uptake as a function of ambient $\mathrm{N}$ reported results as not significant $(d f=1,8 ; f=0.8649 ; p=0.3796)$ and does not pass Shapiro-Wilk $(p<0.05)$; however, this model passed homoscedasticity. 


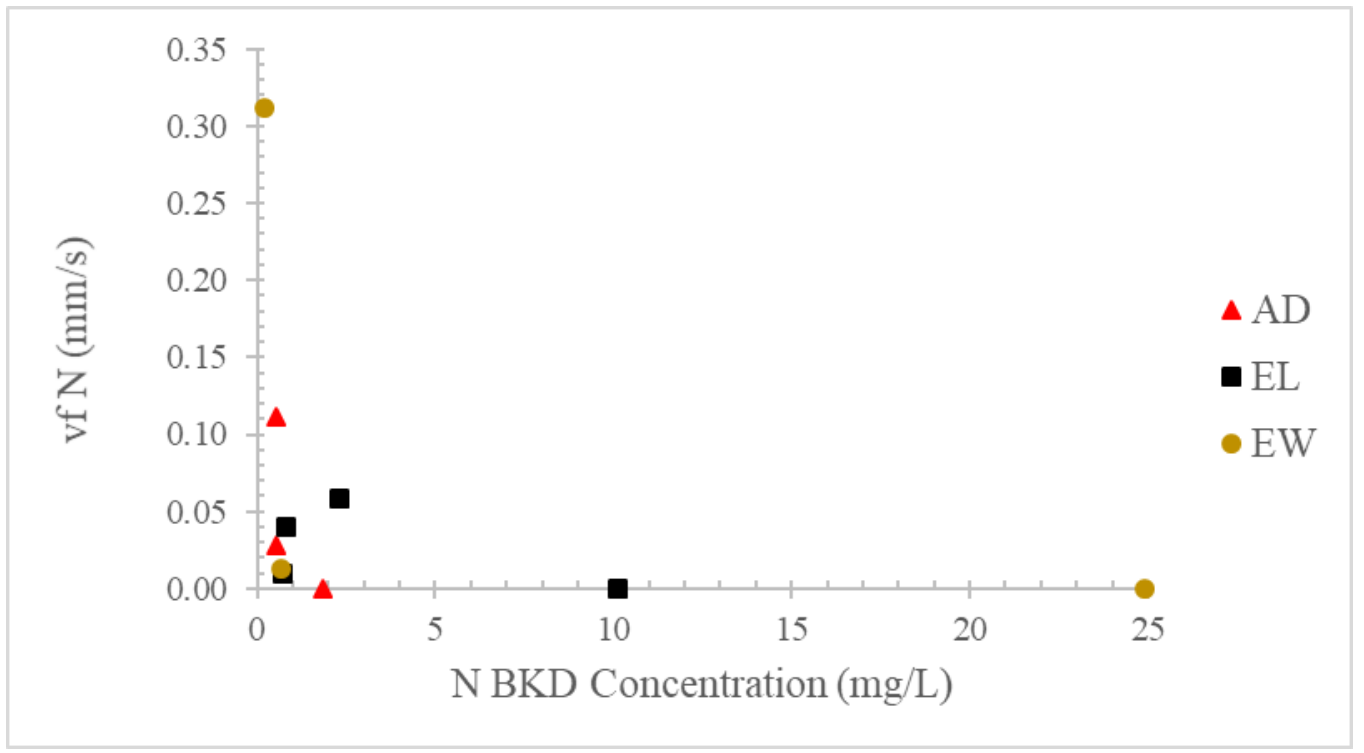

Figure 4: Comparison of $\mathrm{N}$ uptake velocity $\left(\mathrm{v}_{\mathrm{f}} \mathrm{N}\right)$ of sampling sites expressed as a function of background nitrate concentrations (N BKD). Site abbreviations same as tables.

Ambient $\mathrm{P}$ concentrations and $\mathrm{P}$ uptake velocities along the study reaches were not dependent on one another like what was seen in $\mathrm{N}$ uptake (Figure 5). Individual site data plotted within range of each other, except results for Ewing. Ewing had similar P uptake velocities of $0.209 \mathrm{~mm} / \mathrm{s}$ and $0.226 \mathrm{~mm} / \mathrm{s}$; however, these were measured at both high and low background concentrations, $0.008 \mathrm{mg} / \mathrm{L}$ and $0.033 \mathrm{mg} / \mathrm{L}$ (Figure 5). A linear regression analysis of $\mathrm{P}$ uptake as a function of ambient $\mathrm{P}$ reported results as not significant $(d f=1,7 ; f=0.0168 ; p=0.9006)$, meaning ambient $\mathrm{P}$ concentrations do not significantly affect $\mathrm{P}$ uptake velocities. 


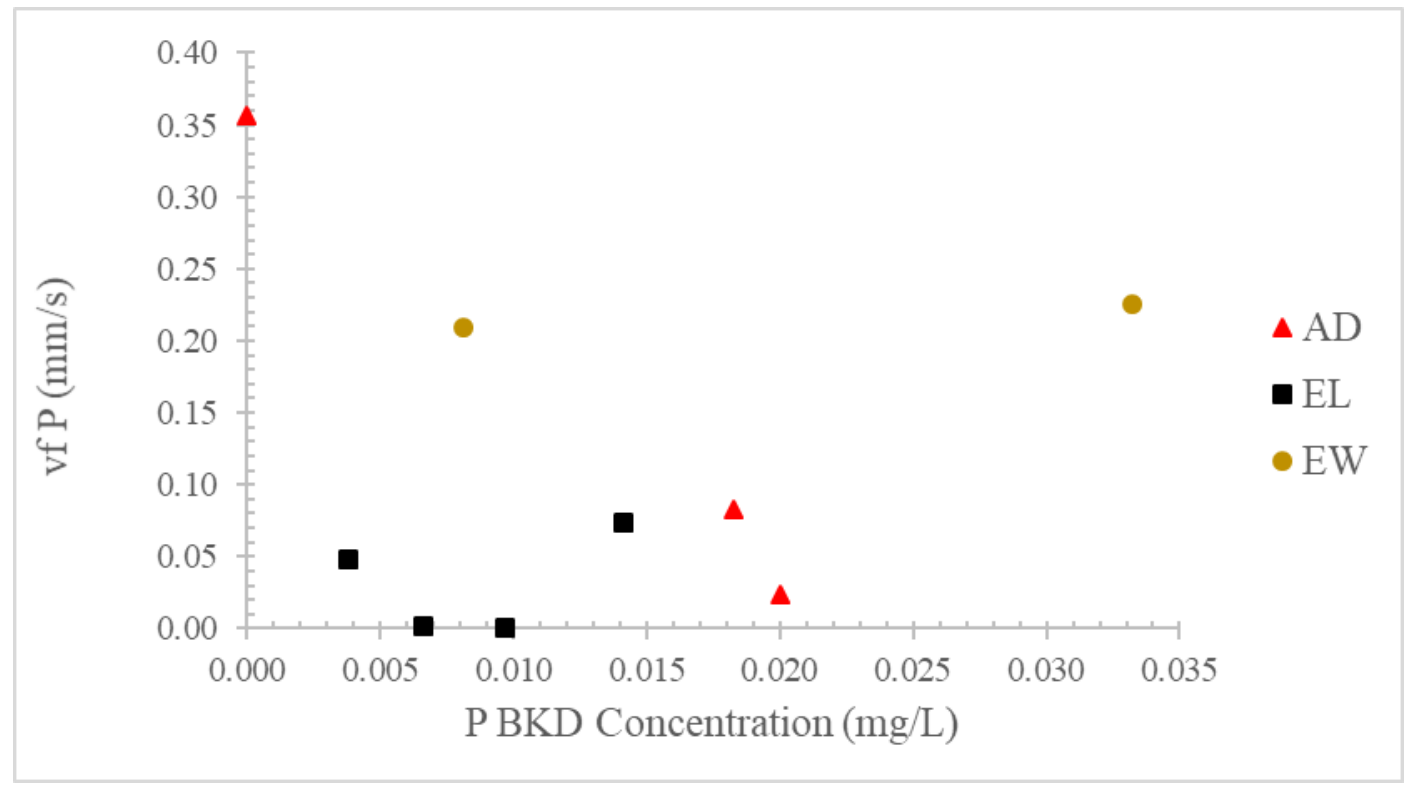

Figure 5: Comparison of $\mathrm{P}$ uptake velocity $\left(\mathrm{v}_{\mathrm{f}} \mathrm{P}\right)$ of sampling sites expressed as a function of background phosphorus concentrations (P BKD).

$\mathrm{N}$ and $\mathrm{P}$ monthly uptake velocities were compared among the three sampled sites (Figure 6). Sampling occurred from mid-July to mid-October 2018. Monthly P uptake velocities measured greater than $\mathrm{N}$ uptake velocities across each site, with the exception of EW 10/1 and EL 9/5 where $\mathrm{N}$ uptake was greater (Figure 6). A linear regression analysis of $\mathrm{P}$ uptake as a function of sampling month reported results as not significant $(d f=1,7 ; f=0.2681 ; p=0.6206)$. 


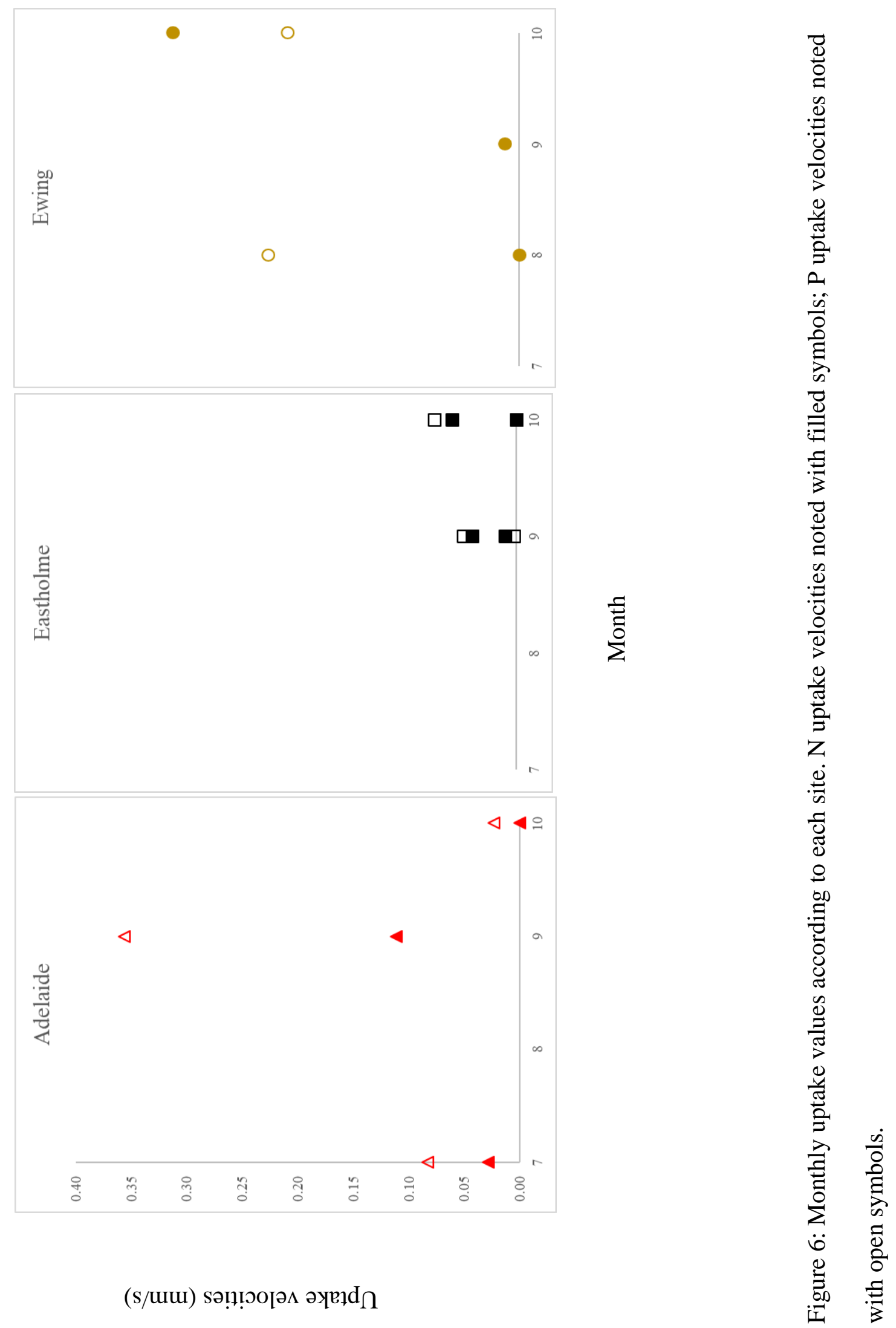


There was no correlation between $\mathrm{N}$ and $\mathrm{P}$ uptake velocities $(r=0.2555)$ (Figure 7a), meaning when there were high $\mathrm{N}$ uptake velocities, $\mathrm{P}$ uptake velocities were not influenced nor effected by N. However, when months were divided before and after leaf fall, $\mathrm{N}$ and $\mathrm{P}$ uptake velocities became more related (before $r=0.5164$, after $r=0.9713$ ) (Figure 7b, 7c). A paired ttest was performed in Excel comparing $\mathrm{N}$ uptake velocity values during the months with/without leaves and $\mathrm{P}$ uptake velocities during the months with/without leaves (Figure 8). Results were not significant for both $\mathrm{N}(d f=4 ; t=0.7557 ; p=0.49)$ and $\mathrm{P}(d f=3 ; t=1.5318 ; p=0.22)$.

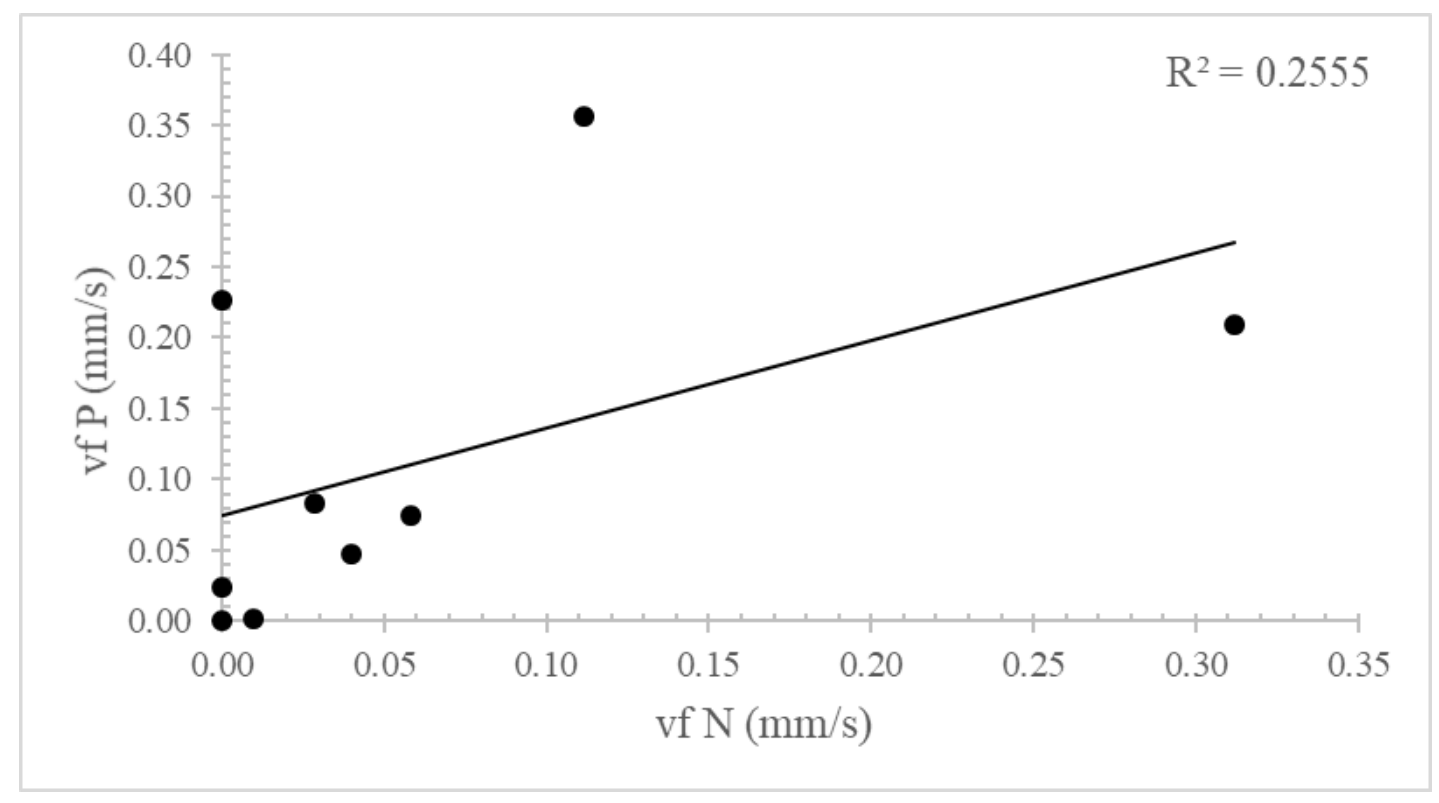

Figure 7: Nitrogen and phosphorus uptake velocity correlations. 7a: $\mathrm{N}$ and $\mathrm{P}$ uptake velocities do not influence one another; therefore, they are not correlated. 


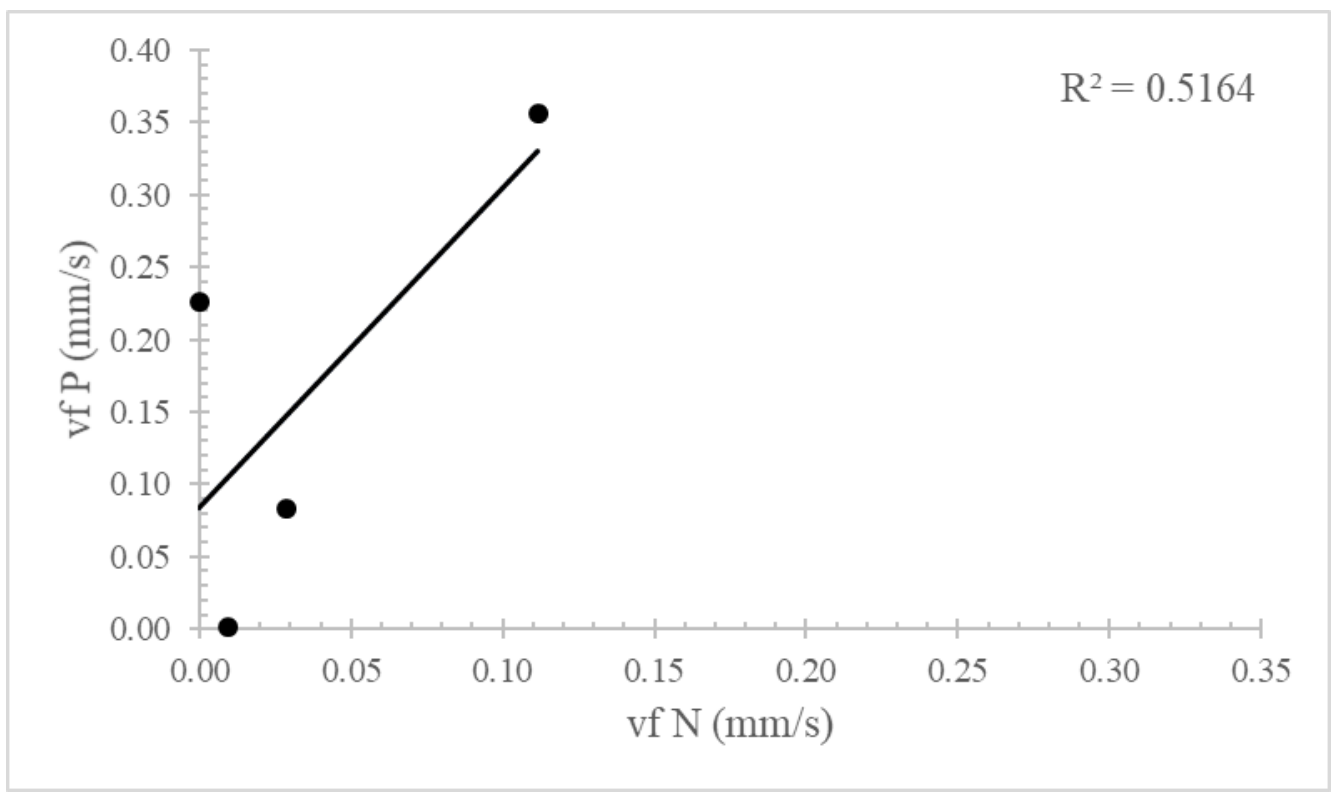

Figure 7b: $\mathrm{N}$ and $\mathrm{P}$ uptake velocities during the time of no leaves present in the stream; 7/23/18 to $9 / 19 / 18$.

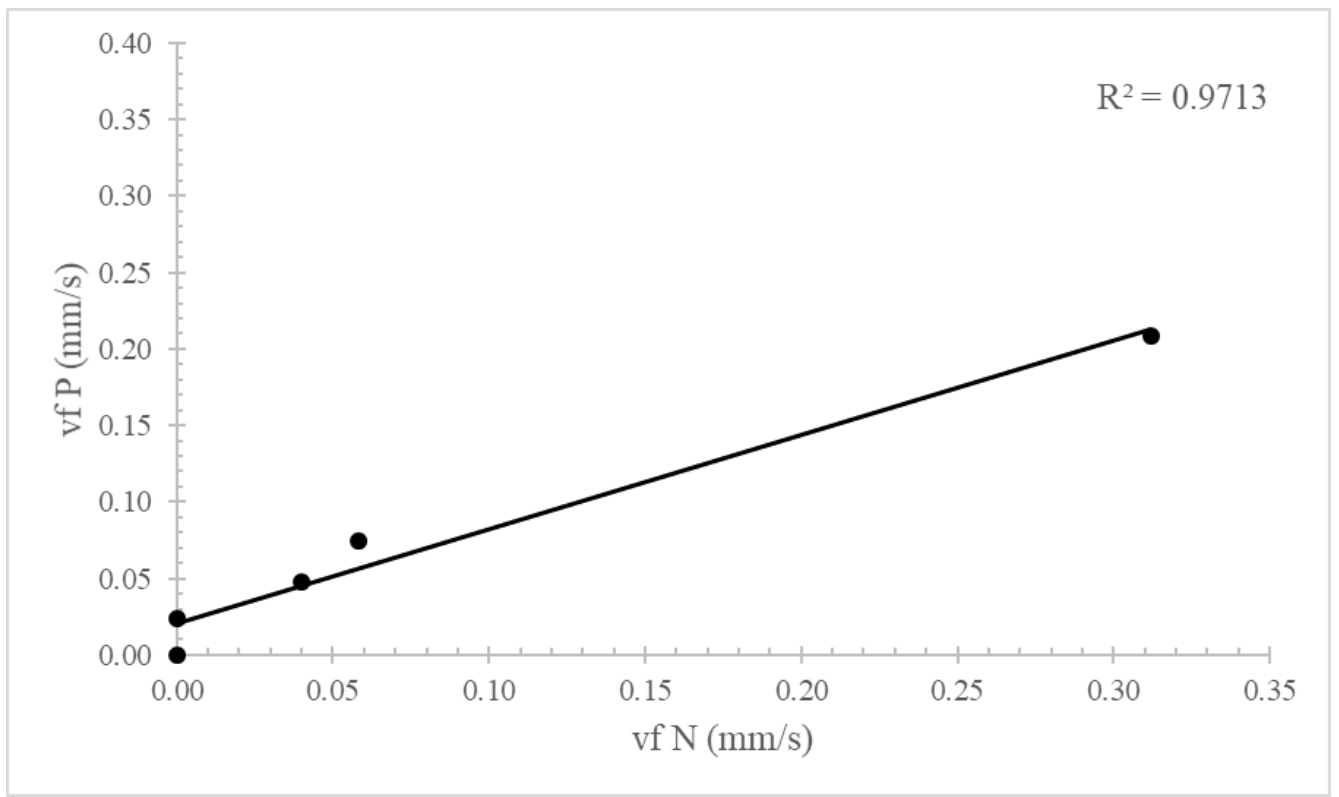

Figure 7c: N and P uptake velocities during time of leaves noted in stream; 9/23/18 to 10/23/18. 


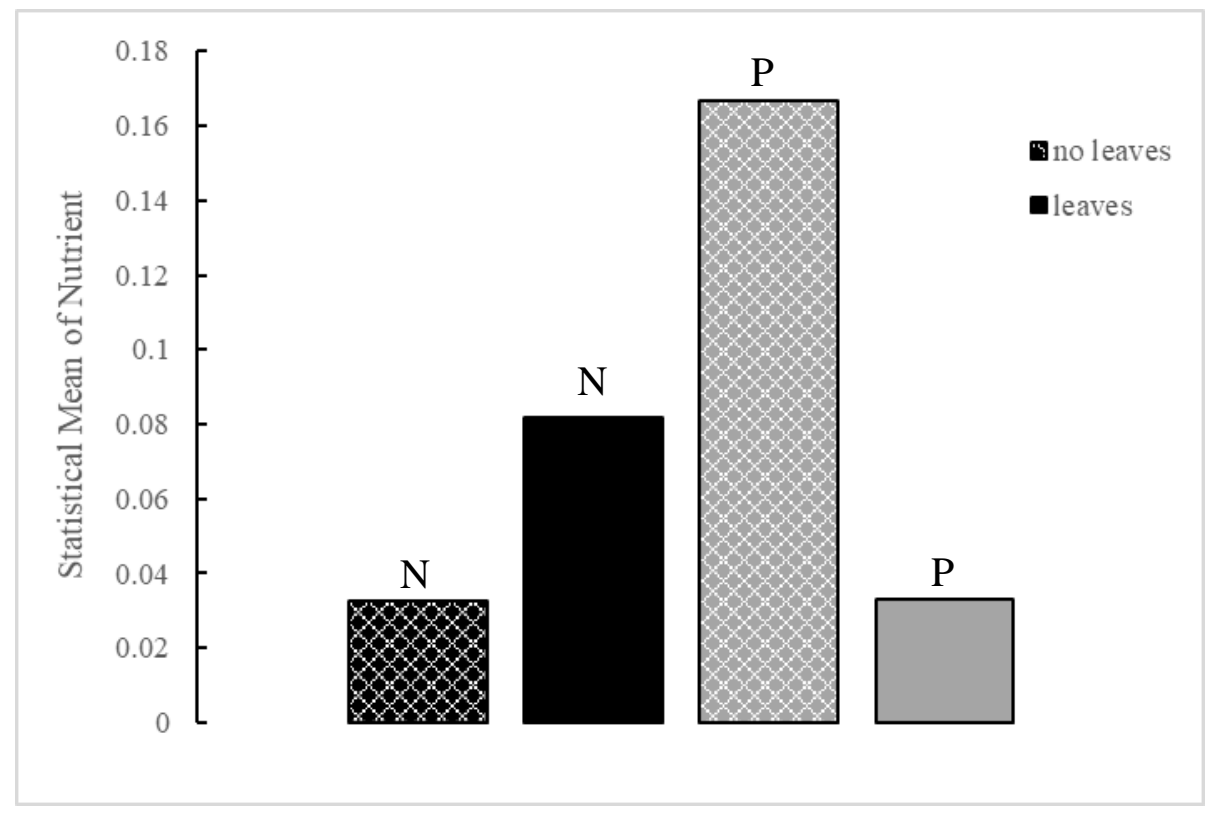

Figure 8: Statistical mean resulting from t-test of $\mathrm{N}$ and $\mathrm{P}$ uptake velocities in the presence and absence of leaves in the study reach of the stream. Black boxes indicate $\mathrm{N}$ uptake, gray boxes indicate $\mathrm{P}$ uptake. Textured hash boxes represent the absence or no leaves, solid boxes represent the presence of leaves. 


\section{CHAPTER IV: DISCUSSION}

\section{Study Comparisons}

$\mathrm{N}$ and $\mathrm{P}$ uptake values that resulted from this study were compared to other stream ecosystems, specifically focusing on streambed composition and environment (Table 4). Uptake velocity values along concrete-lined channels were predicted to be lower than those found along more natural streambeds due to natural streambeds having greater nutrient exchange and microbial biogeochemical processes with the hyporheic zone. Each study possesses its own unique water chemistry, aquatic ecosystem, and climate. These are all influencing factors in uptake values, thus it is difficult to accurately compare. The studies that are represented in Table 4 have been chosen based on the use of similar methodologies and nutrient uptake calculations.

Besides concrete-lined streams, there are other more natural streambeds that have little to no interaction with groundwater. The studies that categorize as having a defined interaction between surface and groundwater include streambed compositions with loose sediments (Newbold, 2013; Hoellein et al., 2007; Argerich et al., 2008), whereas streambed compositions that have limited to no interaction with groundwater include bedrock or concrete (Merseburger et al., 2011; Gibson and O'Reilly, 2012; Grimm et al., 2005). The study conducted in the desert environment would additionally categorize as a stream with no interaction with groundwater (Grimm et al., 2005). Values across these studies were compared; streams with limited to no groundwater interaction generally measured higher uptake velocities, but not for all cases (Table 4). $\mathrm{N}$ uptake values measured in the desert and urban environment best related to the results from this study (Grimm et al., 2005). Interestingly, the two environments that compare the best to a concrete-lined channel also do not have defined hyporheic zones. P uptake values measured in the pasture and forest environments best compared to the results of this study; however, both 
stream compositions are loose sediment (Newbold, 2013; Hoellein et al., 2007). It may be the case that differences in the surrounding environment, climate, and inputs influence microbial processes (and therefore nutrient uptake) along concrete-lined stream, but further investigation is needed.

Table 4: Uptake velocities determined in different environments, as compared to this study's findings (noted by *). The collective range in discharge for Sugar Creek sites was $0.9-68 \mathrm{~L} / \mathrm{s}$. (Merseburger et al., $2011^{[1]}$; and Newbold, $2013^{[2]}$; Hoellein et al., $2007^{[3]}$; Gibson and O’Reilly, $2012^{[4]}$; Argerich et al., $2008^{[5]}$; Grimm et al., $2005^{[6]}$ ).

\begin{tabular}{|c|c|c|c|}
\hline Environment & $\begin{array}{c}\text { Streambed } \\
\text { Composition }\end{array}$ & $\begin{array}{c}\text { N Uptake } \\
\text { Velocity } \\
\text { mm/s }\end{array}$ & $\begin{array}{c}\text { P Uptake } \\
\text { Velocity } \\
\text { mm/s }\end{array}$ \\
\hline Agricultural $^{[1]}$ & Bedrock & $0.007-0.026$ & $0.050-0.31$ \\
\hline Pasture ${ }^{[2]}$ & Sand, silt & $0.002-0.004$ & $0.190-0.300$ \\
\hline Forest $^{[3]}$ & $\begin{array}{c}\text { Terminal moraine; } \\
\text { coarse sediment }\end{array}$ & $0.028-0.314$ & $0.039-0.323$ \\
\hline Forest $^{[4]}$ & $\begin{array}{c}\text { Quartz } \\
\text { conglomerate } \\
\text { bedrock }\end{array}$ & N/A & $<0.083$ \\
\hline $\begin{array}{l}\text { Mountain } \\
\text { (leaves) }^{[5]}\end{array}$ & $\begin{array}{c}\text { Cobbles, boulder, } \\
\text { pebbles }\end{array}$ & $0.032-0.095$ & $0.001-0.008$ \\
\hline $\begin{array}{l}\text { Mountain (no } \\
\text { leaves) }\end{array}$ & $\begin{array}{c}\text { Cobbles, boulder, } \\
\text { pebbles }\end{array}$ & $0.019-0.042$ & $0.009-0.015$ \\
\hline Desert $^{[6]}$ & $\begin{array}{l}\text { Coarse sand, fine } \\
\text { cobble }\end{array}$ & $0.077,0.200$ & N/A \\
\hline Urban (Arid) ${ }^{[6]}$ & Concrete & $0.056,0.120$ & N/A \\
\hline Adelaide * & Concrete & $<0.112$ & $0.24-0.356$ \\
\hline Eastholm * & Concrete & $<0.058$ & $<0.074$ \\
\hline Ewing $*$ & Concrete & $<0.312$ & $0.209,0.226$ \\
\hline
\end{tabular}




\section{Nutrient Uptake Implications}

Lower ambient $\mathrm{N}$ concentrations resulted in higher uptake velocities, while ambient $\mathrm{P}$ concentrations usually had more measurable uptake at higher ambient concentrations; however, $\mathrm{P}$ uptake velocity trends seemed site specific, whereas $\mathrm{N}$ uptake velocities clustered (Figure 4 and 5). In the case of high ambient $\mathrm{N}$, the stream was oversaturated, and as a result, no uptake lengths or velocities could be measured - this was seen for EL 10/23 and EW 8/8 (Figure 4). EL 10/23 and EW 8/8 had the highest recorded ambient $\mathrm{N}$ concentrations of 10.1 and $24.9 \mathrm{mg} / \mathrm{L}$ respectively, but no $\mathrm{N}$ uptake was measured (Table 2 and 3).

Sampling over the course of late summer to early fall, the hope was to document fluctuating $\mathrm{N}$ and $\mathrm{P}$ uptake based on seasonal urban inputs. Instead, P uptake was consistently higher than $\mathrm{N}$ uptake during the sampling period (Figure 6). Stream characteristics such as algal growth and leaf presence may have played a role in $\mathrm{N}$ and $\mathrm{P}$ uptake. Looking at each site individually, Adelaide had low to medium algal growth, and leaf presence was only noted once of the three sample runs (Table 3). At the time of medium algal growth and leaf presence, $\mathrm{N}$ and $\mathrm{P}$ uptake values were recorded as the lowest of the three runs (Table 3). Due to higher ambient $\mathrm{N}$ and $\mathrm{P}$ inputs from possibly the leaves, there was less uptake measured (Table 2 and 3). Higher algal growth and higher frequency of leaves were noted in the study reach at Eastholme (Table 3). $\mathrm{N}$ and $\mathrm{P}$ uptake velocities at Eastholme were smaller than those of the other two study sites, and generally had higher ambient nutrient concentrations (Table 2 and 3). Lastly, Ewing had very little to no algae or leaves during sampling (Table 3). Interestingly, the one time leaves were noted in the reach, $\mathrm{N}$ was greater than $\mathrm{P}$ uptake (Table 3).

Varying monthly uptake velocities may have been a result of sporadic rainstorm events washing away colonies of microbes and algae necessary for uptake to occur. No dry spells 
occurred during the course of the sampling months that led to these stream reaches drying out but flushing of the streambed during high flow events likely disturbed the benthic communities, leading to variable uptake results. Also, depending on the type of microbes and algae that inhabited the stream at the time of sampling may have hindered uptake values, example being green algae and blue-green algae differing in their use of $\mathrm{N}$ and $\mathrm{P}$.

In addition, numerous unseen anthropogenic factors may have influenced the water chemistry of Sugar Creek, resulting in varying uptake measurements. Different amounts of N and $\mathrm{P}$ inputs at different times throughout the four months could have been added into the Sugar Creek system, altering the water chemistry at that time of sampling. Also, during two field collection runs, residents were cutting their lawns, depositing freshly cut grass into the reach.

\section{Sugar Creek Water-Quality}

In this study ambient concentrations of $\mathrm{N}, \mathrm{P}$ and chloride $(\mathrm{Cl})$ were measured for calculating uptake, however this also gave the opportunity to explore the water-quality of Sugar Creek. Urban streams have been a focus in water-quality related studies due to rapid development and land-use change (Cappiella et al. 2012; Coles et al. 2012; Mullaney et al., 2009; Booth et al. 2016).

Ambient concentrations of $\mathrm{N}$ and $\mathrm{P}$ were all under EPA regulations, with the exception of two runs (Table 2). Eastholme and Ewing exceeded the EPA regulation for $\mathrm{N}$-nitrate (10 mg/L), measuring 10.1 and $24.9 \mathrm{mg} / \mathrm{L}$, respectively (Table 2). The high nitrate concentrations may have derived from unseen anthropogenic inputs or from a recent rainfall, but the source is uncertain. No sites exceeded EPA P regulations $(0.05 \mathrm{mg} / \mathrm{L})$; however, some concentrations were within 
$0.03 \mathrm{mg} / \mathrm{L}$ of the limit (Table 2). There was no direct correlation to when there was high ambient nutrient concentrations and the sampled month or site.

Sugar Creek ambient $\mathrm{Cl}$ concentrations exceeded $200 \mathrm{mg} / \mathrm{L}$, with the highest measured concentration being $836.281 \mathrm{mg} / \mathrm{L}$ on $9 / 5 / 2018$ (Table 2). EPA recommended chronic (4-days) standard concentration for aquatic life is $230 \mathrm{mg} / \mathrm{L}$; the acute (1-hour) standard concentration is $860 \mathrm{mg} / \mathrm{L}$ (EPA 1988). A study featuring ecological effects on sodium chloride from road salts measured toxicity thresholds on various aquatic species including algae, desmids, and diatoms (Siegel, 2007). Seigel (2007) reported the toxicity threshold for algae to be $71-36,400 \mathrm{mg} / \mathrm{L}$; 200 - $250 \mathrm{mg} / \mathrm{L}$ for desmids; and $642 \mathrm{mg} / \mathrm{L}$ for diatoms. Such concentrations can hinder growth and chlorophyll production in algae (Siegel, 2007). Consistently high Cl levels in Sugar Creek may have effected uptake results in regard to algae and microbe growth and function. 


\section{CHAPTER V: CONCLUSION}

In this study of urban concrete-lined stream ecosystems, I measured nutrient uptake, focusing on nitrogen as nitrate and dissolved reactive phosphorus. Field collection occurred over late July to mid-October 2018 at three concrete-lined channel sections along tributaries of Sugar Creek in Bloomington-Normal, IL. The first goal of this study was to measure nutrient uptake within this specific stream ecosystem and compare results with those published in other stream environments. My hypothesis was for uptake velocity values to be lower along concrete-lined channels, as compared to streams that have a defined hyporheic zone; this was not supported, and results were not significant. Uptake velocity values along streams with limited to no groundwater interaction generally measured higher uptake velocities, however not true for all environments. The second goal of this study was to determine any seasonal variation in nutrient uptake during the duration of sampling. I proposed summer to have a greater $\mathrm{P}$ uptake velocity due to abundance of $\mathrm{N}$ in stream from fertilizers, while fall having greater $\mathrm{N}$ uptake due to abundance of $\mathrm{P}$ from the decomposition of leaf litter; this was not supported, and results were not significant. Nutrient uptake in Sugar Creek appeared to be constant across the sampled seasons and leaf litter inputs did not appear to have a substantial impact. Additional outcomes of this study have included the opportunity to explore a unique stream environment and focus on the water quality of urban streams.

This study contributes to the research gap on nutrient uptake dynamics along urban concrete-lined stream channels. I used field procedures, laboratory techniques, and equipment similar to previously published nutrient uptake studies; it is these resulting nutrient uptake values that contribute to the disciplines of biogeochemistry and stream ecology. With the concern for urban waterways in light of increasing urbanization, landscape manipulation, development, and 
hydrological alterations, a focus on concrete-lined streams is of importance, especially when these streams are flowing through increasingly dense communities. 


\section{REFERENCES}

Alexander, R. B., Smith, R. A., Schwarz, G. E., Boyer, E. W., Nolan, J. V., and Brakebill, J. W., 2008, Differences in phosphorus and nitrogen delivery to the Gulf of Mexico from the Mississippi river basin: Environmental Science and Technology, v. 42, no. 3, p. 822830.

Booth, D. B., Roy, A. H., Smith, B., and Capps, K. A., 2016, Global perspectives on the urban stream syndrome: Freshwater Science, v. 35, no. 1, p. 412-420.

Bott, T.L., and Newbold, J.D., 2013, Ecosystem metabolism and nutrient uptake in Peruvian headwater streams: International Review of Hydrobiology, v. 98, p. 117-131.

Boulton, A.J., Findlay, S., Marmonier, P., Stanley, E.H., Valett, H.M., 1998, The functional significance of the hyporheic zone in streams and rivers: Annual Review of Ecology and Systemics, v. 29, p. 59-81.

Cappiella, K., Stack, W.P., Fraley-McNeal, L., Lane, C., and McMahon, G., 2012, Strategies for managing the effects of urban development on streams: U.S. Geological Survey Circular 1378.

Coles, J.F., McMahon, G., Bell, A.H., Brown, L.R., Fitzpatrick, F.A., Scudder Eikenberry, B.C., Woodside, M.D., Cuffney, T.F., Bryant, W.L., Cappiella, Karen, Fraley-McNeal, L., and Stack, W.P., 2012, Effects of urban development on stream ecosystems in nine metropolitan study areas across the United States: U.S. Geological Survey Circular 1373.

Eby, G.N., 2004, Principle of Environmental Geochemistry (Eds K. Dodson), p. 110-114. Brooks/Cole Cengage Learning, Belmont, CA. 
Ensign, S. H., and Doyle, M. W., 2006, Nutrient spiraling in streams and river networks: Journal of Geophysical Research-Biogeosciences, v. 111, no. G4.

Environmental Protection Agency (EPA), 2017a, What are combined sewer overflows (CSOs)? Web. https://www3.epa.gov/region1/eco/uep/cso.html.

Environmental Protection Agency (EPA), 2017b, Numeric nutrient criteria table. Web. https://www.epa.gov/nutrient-policy-data/state-progress-toward-developing-numericnutrient-water-quality-criteria.

Environmental Protection Agency (EPA), 2013, Aquatic life ambient water quality for ammonia_freshwater. Web. https://www.epa.gov/sites/production/files/201508/documents/fact_sheet_aquatic-life-ambient-water-quality-criteria-for-ammoniafreshwater-2013.pdf

Environmental Protection Agency (EPA), 1988, Aquatic life ambient water-quality criteria for chloride. Web. https://www.epa.gov/wqc/aquatic-life-ambient-water-quality-criteriachloride-1988.

Environmental Protection Agency (EPA), 1978, Method 365.3: phosphorous, all forms (colorimetric, ascorbic acid, two reagent). Web. https://www.epa.gov/sites/production/files/2015-08/documents/method_365-3_1978.pdf.

Gibson, C.A., and O’Reilly, C.M., 2012, Organic matter stoichiometry influences nitrogen and phosphorus uptake in a headwater stream: Freshwater Science, v. 31, no. 2, p. 395-407.

Grimm, N. B., Sheibley, R. W., Crenshaw, C. L., Dahm, C. N., Roach, W. J., and Zeglin, L. H., 2005, N retention and transformation in urban streams: Journal of the North American Benthological Society, v. 24, no. 3, p. 626-642. 
Hall, R.O. and Tank, J. L., 2003, Ecosystem metabolism controls nitrogen uptake in streams in Grand Teton National Park, Wyoming: American Society of Limnology and Oceanography, v. 48, no. 3, p. 1120-1128.

Hobbie, S. E., Baker, L. A., Buyarski, C., Nidzgorski, D., and Finlay, J. C., 2014, Decomposition of tree leaf litter on pavement: implications for urban water quality: Urban Ecosystems, v. 17 , no. 2 , p. $369-385$.

Hobbie, S. E., Finlay, J. C., Janke, B. D., Nidzgorski, D. A., Millet, D. B., and Baker, L. A., 2017, Contrasting nitrogen and phosphorus budgets in urban watersheds and implications for managing urban water pollution: Proceedings of the National Academy of Sciences of the United States of America, v. 114, no. 20, p. E4116-E4116.

Illinois Department of Natural Resources (IDNR), 2000, Lower Sangamon River Area Assessment: Illinois Department of Natural Resources, v. 1, Springfield, Illinois.

Janke, B. D., Finlay, J. C., Hobbie, S. E., Baker, L. A., Sterner, R. W., Nidzgorski, D., and Wilson, B. N., 2014, Contrasting influences of stormflow and baseflow pathways on nitrogen and phosphorus export from an urban watershed: Biogeochemistry, v. 121, no. 1, p. 209-228.

Janke, B. D., Finlay, J. C., and Hobbie, S. E., 2017, Trees and streets as drivers of urban stormwater nutrient pollution: Environmental Science and Technology, v. 51, no. 17, p. 9569-9579.

Merseburger, G., Marti, E., Sabater, F., Ortiz, J.D., 2011, Point-source effects on N and P uptake in a forested and agricultural Mediterranean streams: Science of the Total Environment, v. 409 , p. $957-967$. 
Minshall, G.W., Petersen, R.C., Cummins, K.W., Bott, T. L., Sedell, J.R., Cushing, C.E., and Vannote, R.L., 1983, Interbiome comparison of stream ecosystem dynamics: Ecological Monographs, v. 53, no. 1, p. 1-25.

Mullaney, J.R., Lorenz, D.L., and Arntson, A.D., 2009, Chloride in groundwater and surface water in areas underlain by the Glacial Aquifer System, Northern United States: U.S. Geological Survey Scientific Investigations Report 2009-5086.

Newbold, J.D., O’Neill, R.V., Elwood, J.W., Van Winkle, W., 1982, Nutrient spiraling in streams: implications for nutrient limitation and invertebrate activity: The American Naturalist, v. 120 , no. 5, p. 628-652.

Robertson, D.M. and Saad, D.A., 2013, SPARROW models used to understand nutrient sources in the Mississippi/Atchafalaya River Basin: Journal of Environmental Quality, v. 42, p. 1422-1440.

Rushforth, H.M., and Hershey, A.E., 2009, Nitrogen uptake and food web nitrogen transfer in a restored urban stream compared to and unrestored urban stream and a pristine stream: Verh. Internat. Verein. Limnol., v. 30, p. 1101-1106.

Schade, J. D., MacNeill, K., Thomas, S. A., McNeely, F. C., Welter, J. R., Hood, J., Goodrich, M., Power, M. E., and Finlay, J. C., 2011, The stoichiometry of nitrogen and phosphorus spiraling in heterotrophic and autotrophic streams: Freshwater Biology, v. 56, no. 3, p. 424-436.

Siegel, L., 2007, I-93 chloride TMDL study: hazard identification for human and ecological effects of sodium chloride road salt: New Hampshire Department of Environmental Services Water Division. 
Tank, J.L., Bernot, M.J., and Rosi-Marshall, E.J., 2006, Nitrogen limitation and uptake: Methods in Stream Ecology (Eds F.R. Hauer \& G.A. Lamberti), p. 213-236. Academic Press, San Diego, CA.

United Nations Department of Economic and Social Affairs (UN DESA), 2018, 68\% of the world population projected to live in urban areas by 2050, says UN. Web. https://www.un.org/development/desa/en/news/population/2018-revision-of-worldurbanization-prospects.html.

United States Army Corps of Engineers, 1995, Structural design of concrete lined flood control channels: Engineer Manual 1110-2-2007. Web. https://www.publications.usace.army.mil/Portals/76/Publications/EngineerManuals/EM_ 1110-2-2007.pdf?ver=2013-09-04-070815-077.

Walsh, C. J., Roy, A. H., Feminella, J. W., Cottingham, P. D., Groffman, P. M., and Morgan, R. P., 2005, The urban stream syndrome: current knowledge and the search for a cure: Journal of the North American Benthological Society, v. 24, no. 3, p. 706-723.

Webster, J. R., and Patten, B.C., 1979. Effects of watershed perturbation on stream potassium and calcium dynamics: Ecological Monographs, v. 49, p. 51-72.

Webster, J.R. and Valett, H.M., 2006, Solute dynamics: Methods in Stream Ecology (Eds F.R. Hauer \& G.A. Lamberti), p. 177-178. Academic Press, San Diego, CA.

Winter, T. C., Harvey, J.W., Franke, O.L., and Alley, W.M., 1998, Ground water and surface water: a single resource, Denver, CO, U.S. Dept. of the Interior, U.S. Geological Survey, U S Geological Survey circular, v. 1139, vii, p. 79. 
APPENDIX A: FIELD OBSERVATIONS

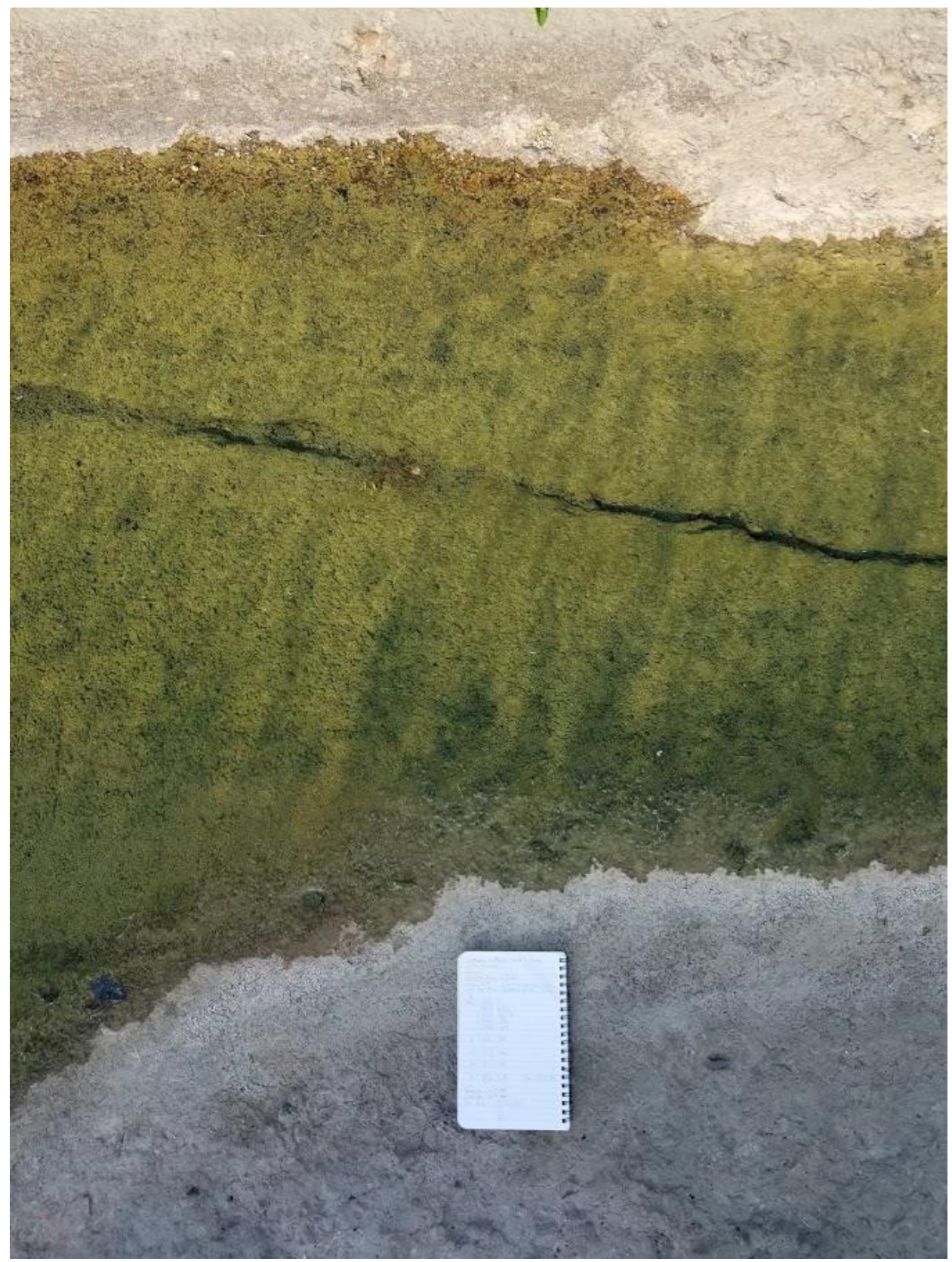

$9 / 5 / 2018$

Eastholme Ave.

Field Description: Sunny, $91^{\circ}$ F. Slow-medium flow. Medium algae.

Fresh cut grass present. 


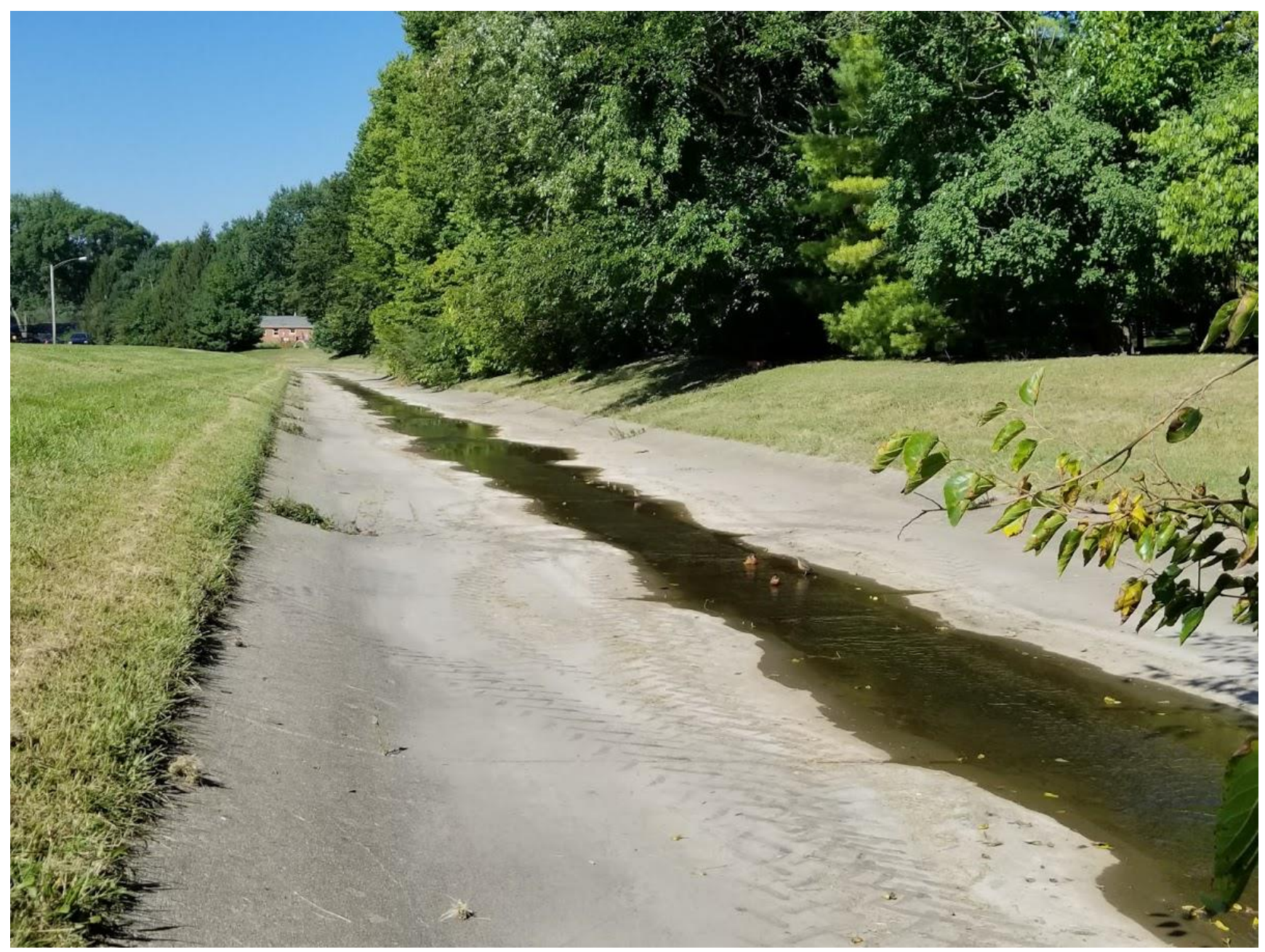

$9 / 15 / 2018$

Ewing Park

Field Description: Sunny, $82^{\circ}$ F. Medium flow. Clear, little to no algae. Fresh cut grass present. 


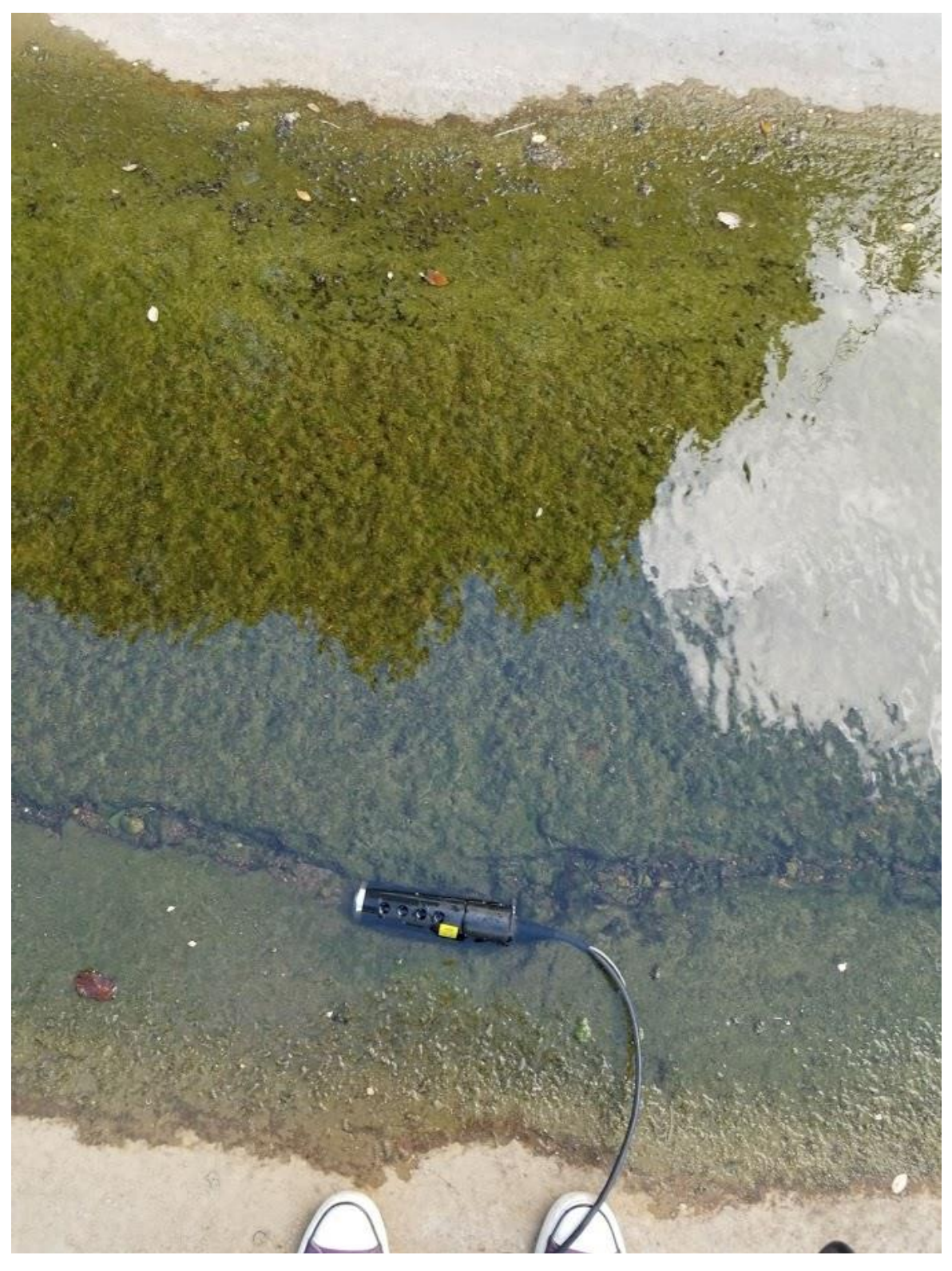

9/19/2018

Adelaide St.

Field Description: Sunny, $89^{\circ}$ F. Slow-medium flow. Medium algae. Fish present. 


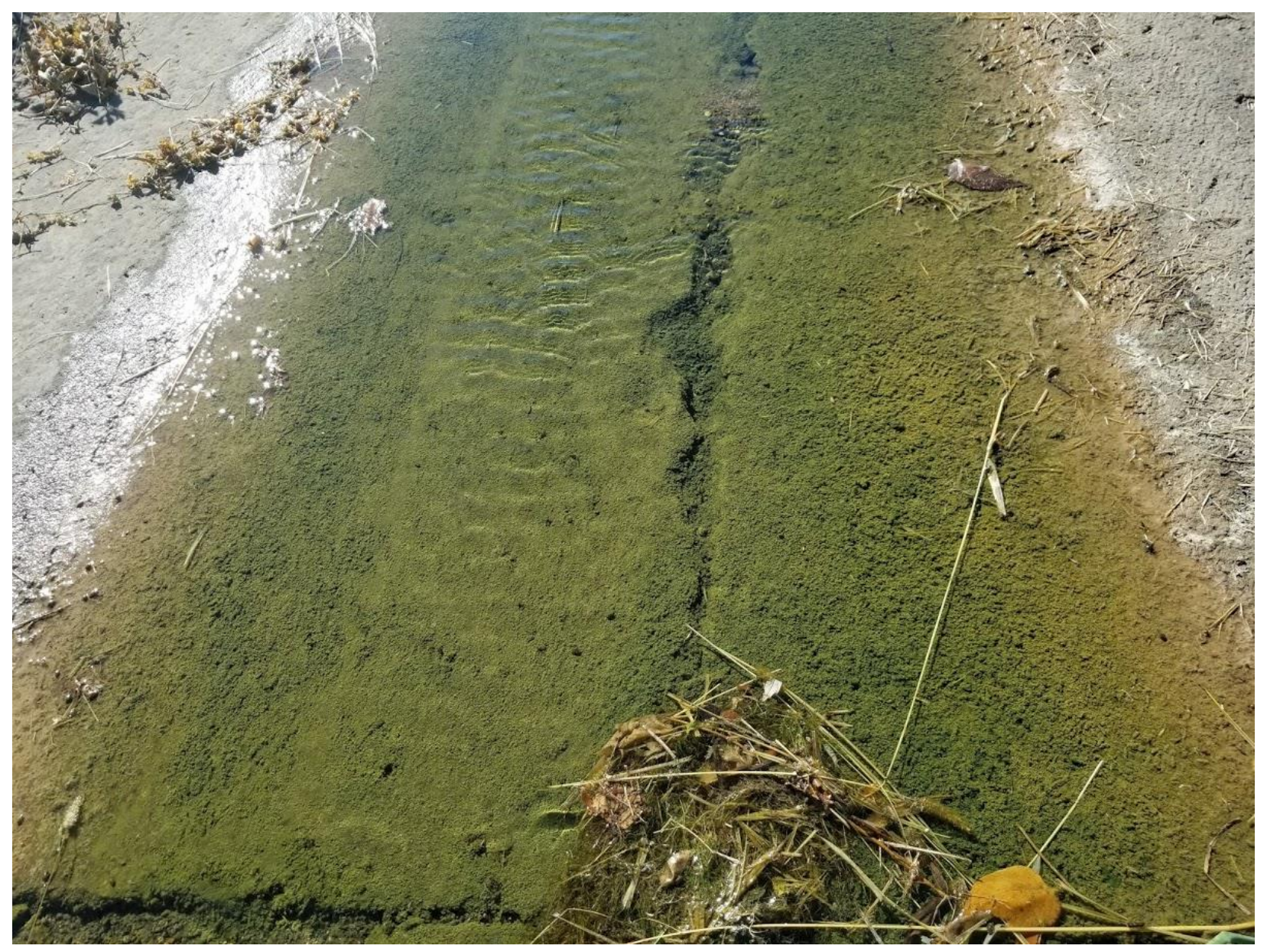

9/23/2018

Eastholme Ave.

Field Description: Sunny, $63^{\circ}$ F. Slow-medium flow. Medium mottled algae. Cut grass and leaves present. 


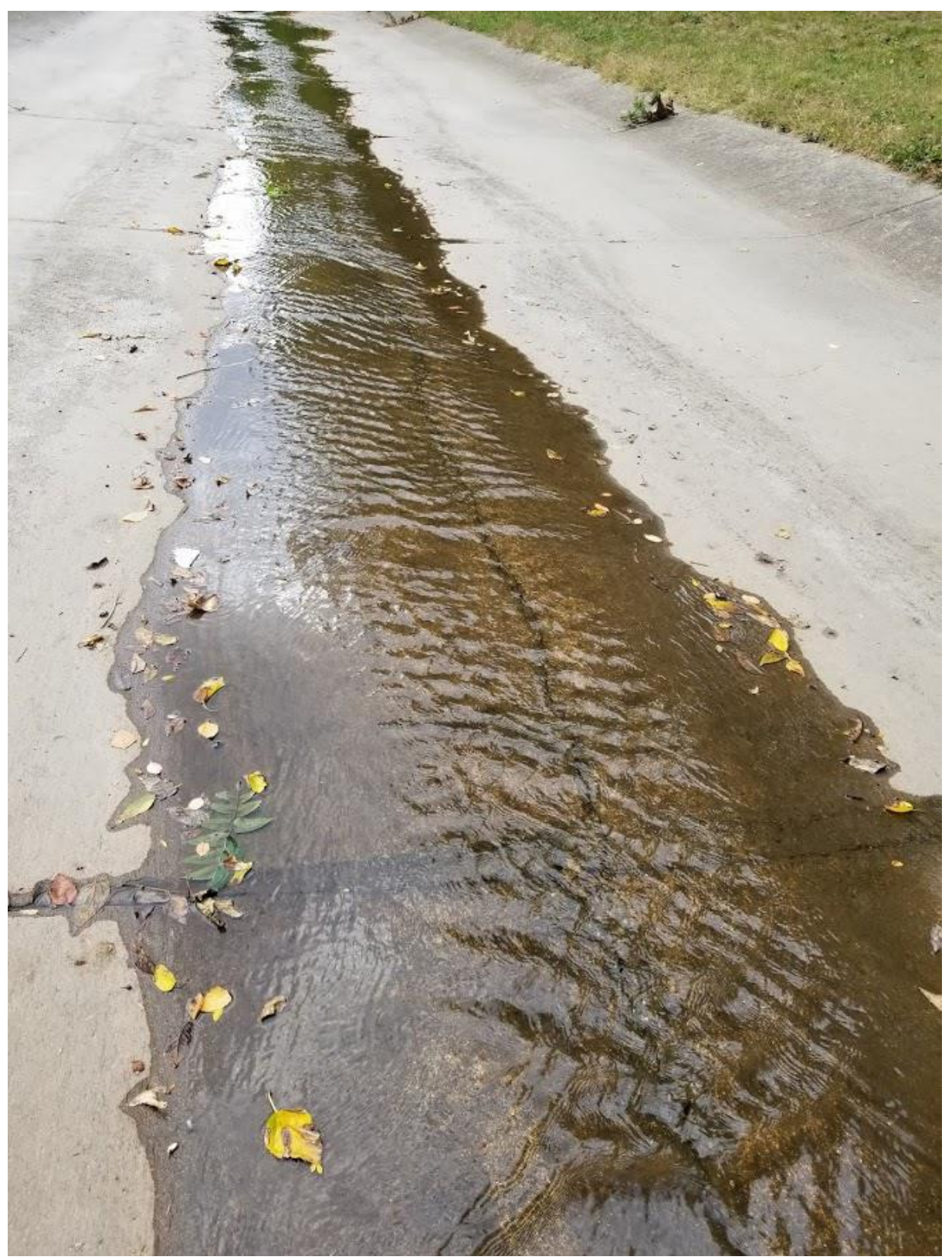

$10 / 1 / 2018$

Ewing Park

Field Description: Overcast, $81^{\circ} \mathrm{F}$. Medium-fast flow. Very little algae. Some leaves present. 


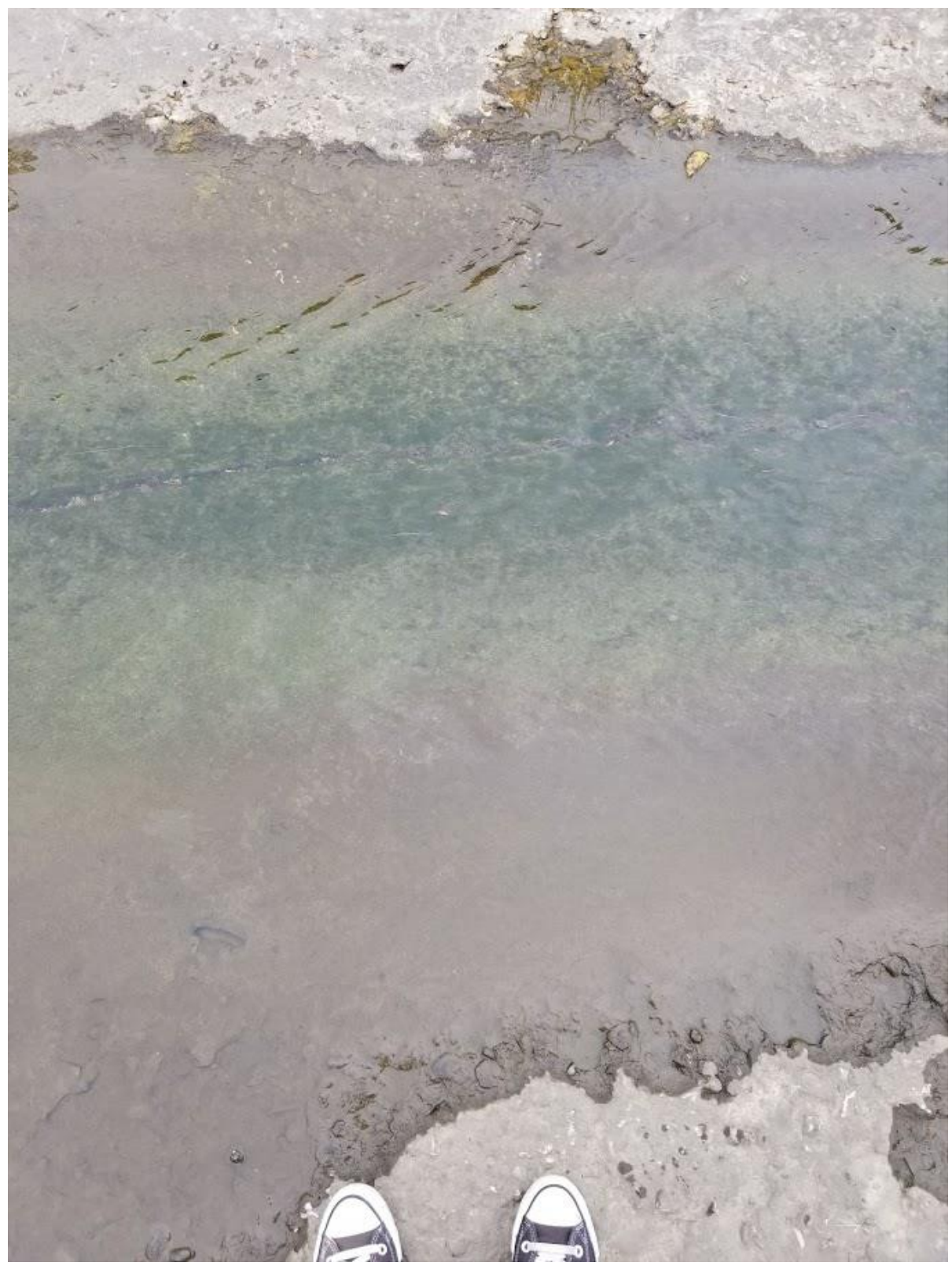

$10 / 14 / 2018$

Eastholme Ave.

Field Description: Overcast, $46^{\circ} \mathrm{F}$. Fast flow. Very little algae. 


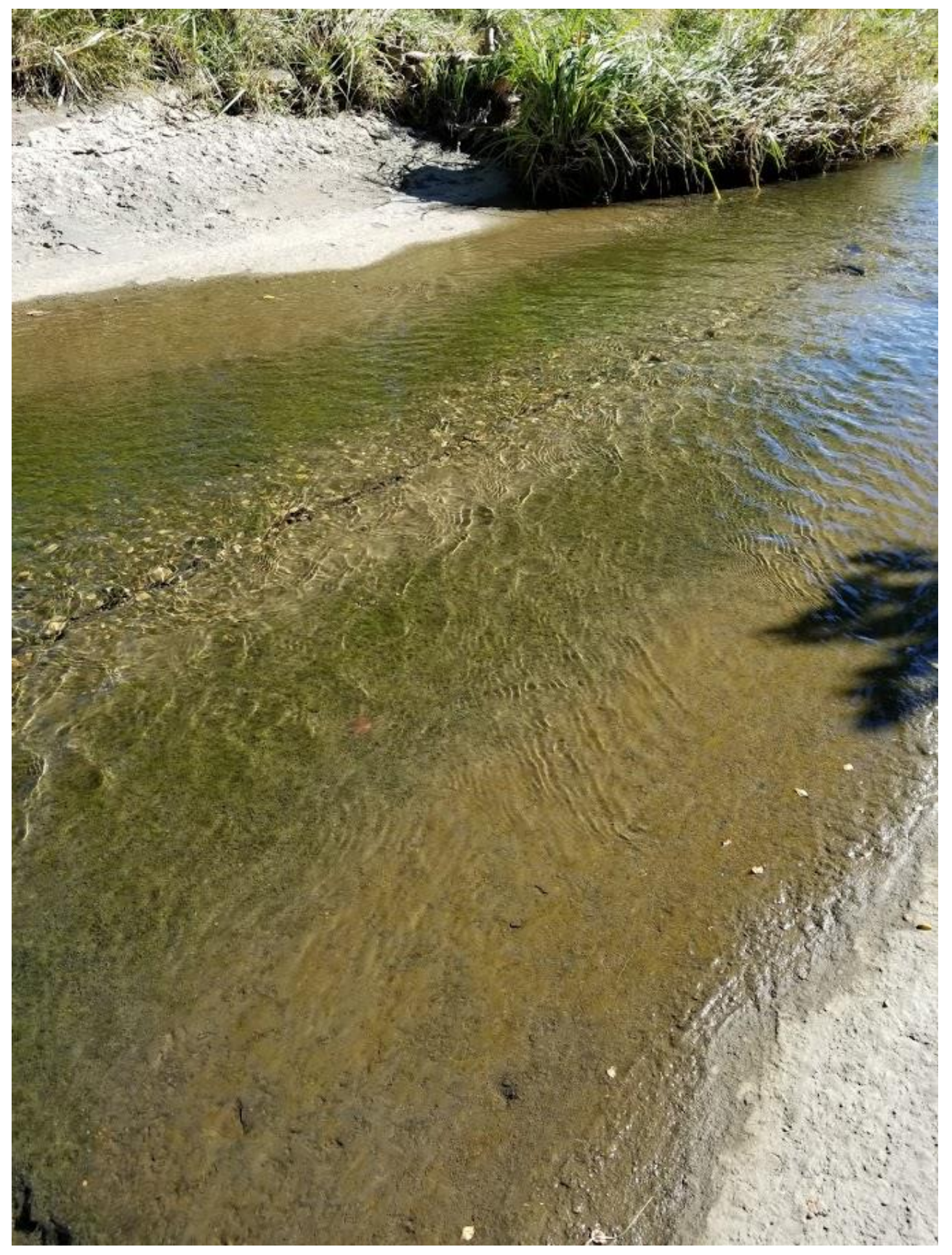

$10 / 16 / 2018$

Adelaide St.

Field Description: Sunny, $54^{\circ} \mathrm{F}$. Fast flow. Medium algae, strips of thin algal mats. 


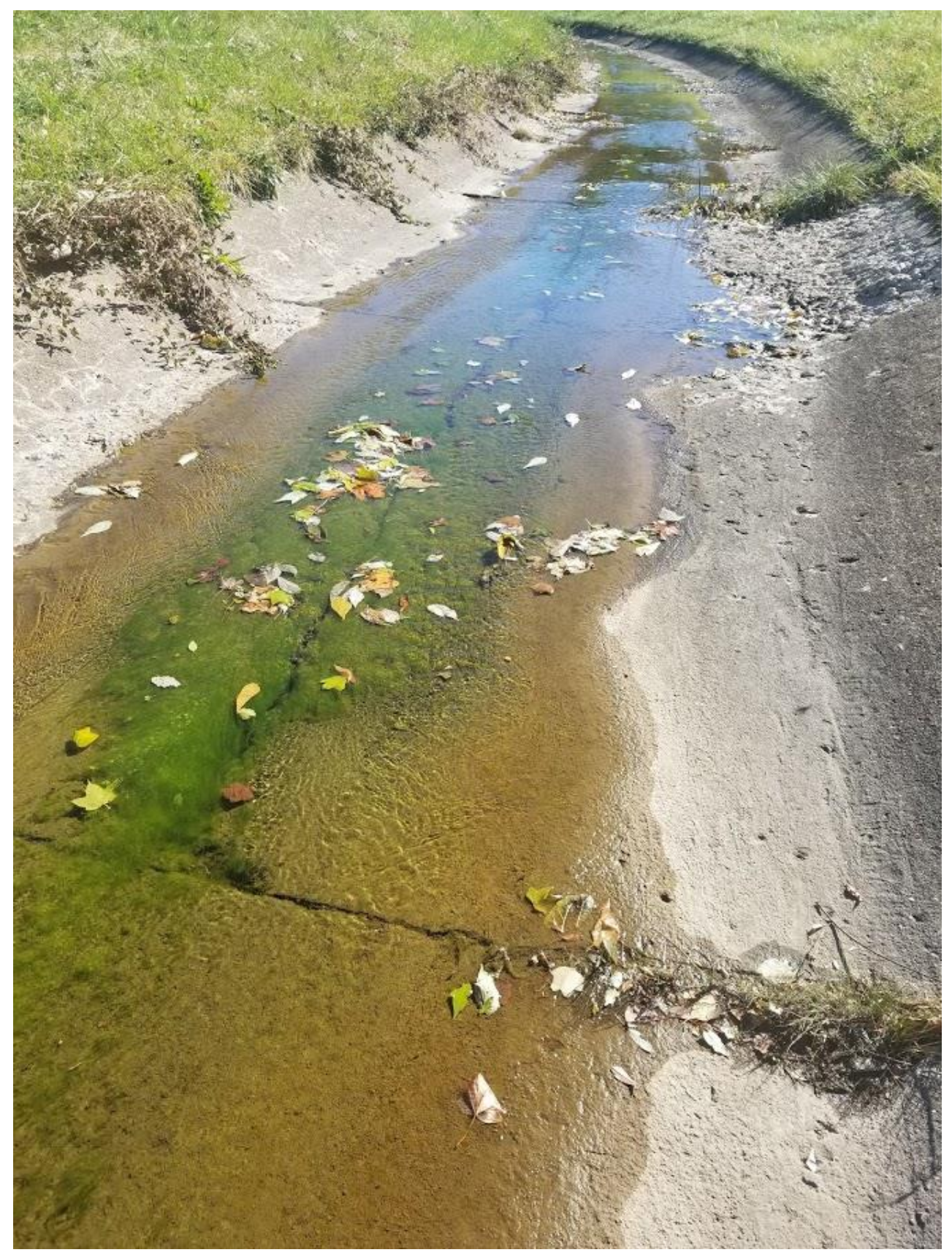

$10 / 23 / 2018$

Eastholme Ave.

Field Description: Sunny, $50^{\circ} \mathrm{F}$. Medium flow. Dense, spongy algal mats. 